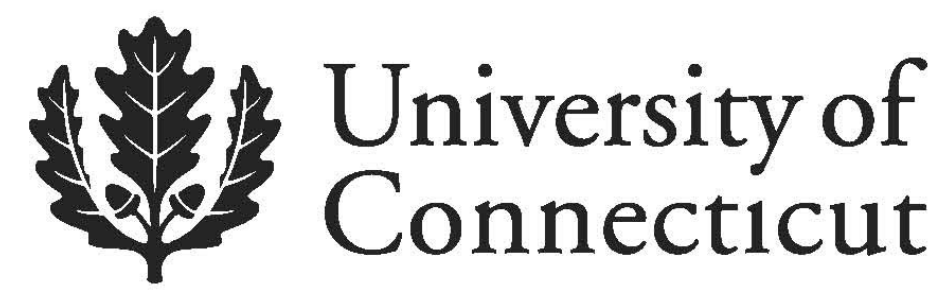

Department of Economics Working Paper Series

Impact of Liberalization and Globalization on Productivity in Indian Banking: A Comparative Analysis of Public Sector, Private, and Foreign Banks

Subhash C. Ray

University of Connecticut

Working Paper 2012-02

January 2012

341 Mansfield Road, Unit 1063

Storrs, CT 06269-1063

Phone: (860) 486-3022

Fax: (860) 486-4463

http://www.econ.uconn.edu/

This working paper is indexed on RePEc, http://repec.org/ 


\title{
Impact of Liberalization and Globalization on Productivity in Indian Banking: \\ A Comparative Analysis of Public Sector, Private, and Foreign Banks
}

\author{
Subhash C Ray \\ University of Connecticut \\ Storrs CT 06269 USA \\ subhash.ray@uconn.edu
}

\begin{abstract}
Although dominated by public sector banks, India already had a significant presence of private domestic banks and foreign banks. What the banking reforms have done is to create a more level playing field where banks of different ownership types compete within a new set of broad (and far more relaxed) regulations. Data on the performance of the three different categories of banks over the past two decades offer an opportunity to assess to what extent the regulatory changes have improved the productive efficiency of the banking sector in India. Apart from analyzing the standard descriptive measures of performance, this paper uses the nonparametric approach of Data Envelopment Analysis to measure total factor productivity growth and its components to assess the impact of liberalization on different ownership categories of banks in India. The broad conclusion is that it is possible to promote financial soundness by introducing proper prudential norms and to improve operational efficiency without wholesale privatization by allowing competition between public, private and foreign banks. This can be a valuable lesson for other developing countries.
\end{abstract}

This paper was prepared for the WTO-UNCTAD Conference in Delhi in November 2011. The author is grateful to Abhiman Das for providing him the data in a readily usable form and also for valuable comments. The usual disclaimer applies.

JEL Classification: G21; C61

Key words: Banking Reforms; Data Envelopment Analysis; Efficiency Analysis 


\title{
Impact of Liberalization and Globalization on Productivity in Indian Banking:
}

\section{A Comparative Analysis of Public Sector, Private, and Foreign Banks}

\author{
Subhash C Ray \\ University of Connecticut \\ Storrs CT 06269 USA \\ subhash.ray@uconn.edu
}

\begin{abstract}
Although far less sweeping than the economic reforms in post-Mao China and decidedly less spectacular than the collapse of the former Soviet Union, the Indian economic reforms are of great interest throughout the world not only because it affects the lives of over a billion human beings but also because it can offer valuable lessons for other developing nations. The main components of liberalization in an economy that has been under strict government control over years are downsizing (if not eliminating) the public sector creating room for domestic firms and allowing entry of foreign firms. In this respect, Indian banking industry provides an ideal setting for evaluating the impact of liberalization and removing entry restrictions. Although dominated by public sector banks, India already had a significant presence of private domestic banks and foreign banks. What the banking reforms have done is to create a more level playing field where banks of different ownership types compete within a new set of broad (and far more relaxed) regulations. Data on the performance of the three different categories of banks over the past two decades offer an opportunity to assess to what extent the regulatory changes have improved the productive efficiency of the banking sector in India.
\end{abstract}

The history of modern banking in India goes all the way back to the early days of East India Company Rule when the General Bank of India was established in 1786. Subsequently, three Presidency Banks were established in Calcutta, Bombay, and Madras in the beginning of the $19^{\text {th }}$ Century. These banks operated as independent entities until 1921 when they were merged to form the Imperial Bank of India. Subsequently Reserve Bank of India (RBI) was established as the central bank of the country in 1935. Many privately owned domestic banks (like Bank of Baroda, Canara Bank, and Punjab National Bank) emerged as part of the Nationalist movement. By the time India gained independence in 1947, there were many foreign and privately owned domestic banks in the scene. In 1949 RBI was nationalized and was given wide supervisory powers over other banks in the country. 
Inspired by the Nehruvian ideal of a socialistic society and the Soviet example of rapid industrialization through collectivist planning, India adopted a strategy of planned economic development assigning a dominant role to the public sector. Financing the huge expenditure on large scale projects required intermediation of a major share of loanable funds to the public sector principally through the banks. This made strict government control of commercial banks almost inevitable. As a first step in this direction, the former Imperial Bank of India was nationalized in 1955 and State Bank of India (SBI) was formed as a wholly owned subsidiary of RBI.

Subsequently, SBI acquired the state owned banks in eight former princely states in 1959. As a result, a significant part of the banking sector came under government ownership. By July 1969 about $31 \%$ of scheduled bank branches were under government control. It was felt, none the less, that privately own banks were not lending enough to those who needed credit most. Another 14 private banks each with deposits over Rs.500 million were nationalized in 1969 in an effort to address this problem. As a result, the share of bank branches under government control increased to $84 \%$. Finally, in 1980, six more private banks with deposits exceeding Rs. 2 billion were nationalized leaving a mere $10 \%$ of bank branches in private control.

There was no further nationalization of any private bank thereafter. However, rigid regulatory control ensured that banks effectively served as channels for implementing the various fiscal policies of the government by providing it easy and low cost access to funds for its preferred projects. Apart from the required cash reserve ratio (CRR) banks were also subjected to a Statutory Liquidity Ratio (SLR) that forced them to hold a mandated proportion of their credit in the form of government securities. Not surprisingly the administered interest rates on these securities were below the market rate. Interest rates on loans and deposits were also strictly regulated by the government instead of being determined by the market. Moreover, since 1969 banks were required to extend at least $33 \%$ of their total credit to the priority sector (consisting of agriculture and small scale industries) that was not adequately served otherwise. Subsequently the priority sector lending requirement was raised to $40 \%$. One must admit that directed lending targeted towards the priority sector did channel a significant amount of credit to agriculture and also led to a major expansion of the branch network of (public sector) banks in the rural areas. In that sense, it helped to achieve the social banking objectives of the government. Never the less, it was a period of severe financial repression that jeopardized the viability of many banks by the end of the 1980s. Profitability had declined from $23 \%$ in 1975 all the way down to $9 \%$ of total business (i.e., deposits plus credit) in 1984. 
Although there were signs of gradual loosening of the tight grip of the government on commercial banks as early as in 1986, the banking sector reforms launched by RBI in 1991 based on the recommendations of the first Narasimham Committee on Financial Sector Reforms ended the era of rigid government control of banks and altered the structure of the banking industry by allowing entry by new private and foreign banks. It may be noted that unlike in many other countries, these banking sector reforms were not triggered by any impending crisis. Nor were the reforms designed by any multi-lateral aid agency. Instead, they were indigenously formulated. Also, while provisions were made for expanding the shares of domestic private and foreign banks, there was no attempt to end government ownership by large scale privatization of the existing public sector banks. Accommodation of new private domestic and foreign banks has led to a decline of the share of public sector banks in the total assets of the banking sector from $90 \%$ in 1991 to less than $74 \%$ in 2010 . While somewhat downsized, public sector banks as a whole continue to dominate the entire banking industry even after nearly two decades since the reform was launched. Another interesting point needs to be noted. There was an initial phase of infusion of capital into the public sector banks by the government. Subsequently, their capital base was expanded by allowing private equity participation up to a maximum of $49 \%$. Diversification of ownership diluted but did not eliminate their public sector character. At the same time, these banks now became accountable to the shareholders and needed to improve efficiency.

While the first phase of financial reforms guided by the Report of the Narasimham Committee I (1991) was primarily designed to introduce 'operational flexibility' and functional autonomy in order to improve productivity and efficiency of banks, the second phase based on the subsequent Report of the Narasimham Committee II (1998) addressed the question of financial stability of the banking sector. Over the years of banking under rigid government control the accumulating burden of nonperforming loans (NPL) reached alarming proportions threatening the solvency of many banks. To bring about financial stability, RBI adopted prudential banking norms consistent with the Basel Accord (1988) and the subsequent Basel II (2004). The three main components of these norms are (a) minimum capital requirement (enforced through statutory minimum capital to risk-weighted asset ratio (CRAR)) (b) supervision and monitoring of risk management, and (c) transparency in disclosure of specific variables that would enable financial markets to appropriately evaluate the bank. In India the mandatory capital adequacy ratio was set at 9\% which exceeds the international norm of $8 \%$.

The main features of the banking reforms can be summarized as follows: 
- Increased competition introduced by more liberal rules for entry by new domestic and foreign banks.

- Initial infusion of government capital to rejuvenate public sector banks followed by allowing private ownership of up to a maximum of $49 \%$ of total equity. In fact, up to $20 \%$ of private equity can be held by foreign individuals and financial institutions.

- Foreign direct investment in private banks is allowed up to a limit of $75 \%$.

- Deregulation of interests on both deposits and loans.

- Reduction in Statutory Lending Requirement and Cash Reserve Requirements to ameliorate financial repression and reduce pre-emption of bank lending.

- Widening the coverage of 'priority sector'.

- Introduction and phased implementation of international best practices and norms on risk-weighted capital adequacy requirements, accounting, income recognition, provisioning, and exposure.

- Promulgation of Securitization and Reconstruction of Financial Assets and Enforcement of Securities Interest (SARFASEI) Act and its subsequent amendment to ensure creditors rights.

- Setting up Credit Information Bureau for information sharing on defaulters and other borrowers.

- Establishment of the Board of Financial Supervision as the apex supervisory authority for banks, financial institutions, and non-banking financial companies.

- Introduction of the so called CAMELS supervisory rating system in an effort to introduce risk-based supervision.

- Enhancing corporate governance through greater transparency norms supplemented by market discipline.

Over the years the share of NPL in total loans has declined dramatically. For example, the ratio of NPL to total advances declined from $15.7 \%$ in $1996-97$ to $2.4 \%$ in $2009-10$ for all scheduled 
commercial banks. For Public sector banks the corresponding decline was from 17.8\% in 1996-97 to $2.2 \%$ in $2009-10$.

Not surprisingly, the impact of the banking reforms on the performance of Indian banks of different ownership categories has been researched extensively in numerous papers published over the past years. These can be grouped into two broad categories. Papers in the first category are essentially descriptive and compare popular measure of performance like business per employee, intermediation cost per Rupee of assets, credit-deposit ratio, or percentage of NPL in total credit over years and across ownership types of banks. Although highly informative and quite comprehensive in summarizing the changes between the pre- and post-Reform decades, they are not grounded in any underlying conceptualization of a production process in the banking industry. Measurement of productivity in the service sector is always difficult. For banking it is more so because there is no consensus about how to define outputs and inputs of a bank. In the production approach a bank is perceived ad providers of deposit and credit services to its customers. By contrast, in the intermediation approach the bank is deemed primarily to be in the business of converting deposits into loans. However, once a particular approach is chosen, one can formulate an analytical framework for empirical evaluation of productivity and efficiency. Papers in the normative strand in the literature use data to construct a production, cost, or profit function as a benchmark for comparison with the actual output, cost, or profit of a bank. Depending on the perceived objective of the bank one would measure efficiency using output maximization, cost minimization, or profit maximization as the criterion.

This paper unfolds as follows. Section 2 summarizes the main findings from the extant literature. Section 3 briefly introduces the production economics concepts that provide the basis for measurement of efficiency and productivity change. Section 4 describes the nonparametric methodology that has been used in this study. Section 5 reports the main findings from this study.

\section{Literature Review}

There are several papers by leading experts on Indian banking that provide a comprehensive overview of the banking reforms as an integral part of Financial Sector Reforms in India. Mohan (2004, 2005), Reddy (2005, 2008), and Rangarajan (2007) have described the motivation for and objectives of the reforms and have also looked into the initial experience of the Indian banking sector during the post reform era. Mohan $(2004,2005)$ in particular, highlighted the interrelationship between financial development and economic growth and assessed the impact of the reforms on efficiency and productivity of banks using a number of alternative measures of 
performance like business per employee, intermediation cost (as percentage of total assets), costincome ratio, and net interest margin. For the banking sector as a whole, there is clear evidence of decline in operating cost per unit of earning asset (often viewed as the unit cost of output). It fell from $2.08 \%$ in 1992 almost steadily (except for a sudden increase in 1995 and 1996) to $1.78 \%$ in 2004. As for intermediation cost (i.e. operating expense) as a percentage of earning assets, Indian private banks showed the maximum improvement lowering it from $2.97 \%$ in 1992 to $2.01 \%$ in 2004. In fact, by this criterion, both public sector banks, and private domestic banks were more efficient that foreign banks. But as Mohan (2004) cautioned, the lower intermediation cost must be weighted against the large expenditure incurred on upgrading the information technology and institution of 'core banking'. A different measure of performance is the cost-income ratio. For all scheduled commercial banks, the percentage of net income spent on operating cost declined from 55.3\% in 1992 to $45.1 \%$ in 2004. Compared to domestic banks (both public and private) foreign banks had lower cost-income ratio. The share of net NPL (net of provisioning) in total advances of all commercial banks also showed a decline from $8.1 \%$ in $1996-7$ to $3.0 \%$ in $2003-4$. As Mohan (2004) explained, there were several factors behind this decline. First, the high NPL accumulation in the banking sector was a legacy of poor credit decisions taken before the reforms and were carried over from the past. Second, an improvement in credit appraisal has lowered the incremental accumulation of NPL even during a low growth phase of the economy in the late 1990s. Third, public sector banks have been more successful in loan recovery than the private domestic banks. Of course foreign banks have had a better recovery ratio and lowest NPL ratio among all ownership groups. Overall, Mohan $(2004,2005)$ has provided ample evidence for the claim that the reforms have brought about significant improvement in the performance of scheduled commercial banks in India, in general, and public sector banks, in particular.

While an overall assessment of banking reforms in terms of their impact on the productivity of banks in India is valuable, it usually is more descriptive than analytical. By contrast, the empirical studies define a technological relationship between inputs and outputs (although the studies vary widely in how input-outputs are chosen) and draw conclusions about productivity and efficiency change from rigorous analysis of bank level data. This reduces the danger of casual empiricism often present in simple comparison of means across groups.

In one of the early studies of the impact of the reforms, Bhattacharyya, Lovell, and Sahay (1996) analyzed the efficiency of public, private, and foreign banks using data from the period 1986-91. The time period is best described as the transition years of early deregulation before banking sector reforms were formally launched. They included deposit, credit, and investment as outputs. 
Interest expenses and operating expenses were treated as the two inputs. Their findings showed that public sector banks were the most and private banks were the least efficient with foreign banks lying in between. They found that over the years covered public sector banks improved in efficiency while efficiency of public sector banks tended to decline over years.

Covering a longer time period (1985-96) Kumbhakar and Sarkar (2003) estimated a Translog shadow cost function for public and private banks in India. The outputs included were (a) Fixed Deposits, (b) Savings Deposits, (c) current deposits, and (d) investments. Capital and Labor were treated as variable inputs and equity (including reserves) as fixed input. They found that there was significant input price distortion due to regulation. This resulted in over-employment of labor relative to capital over the entire sample period in both public and private sector banks. This distortion declined gradually although somewhat faster for private sector banks. In fact by 1996 shadow price of labor differed little from the market price for private banks. As regards productivity growth no significant improvement was found for public sector banks in the postderegulation years. Private banks experienced a higher rate of productivity growth compared to public sector banks. Also, for this ownership category, the rate of productivity growth was higher during 1992-96 compared to 1985-91.

Ram Mohan and Ray (2004) used data for the years 1990-2000 to measure revenue maximization efficiency of the three categories of banks. Public sector banks were found to be significantly more efficient than private banks in maximizing revenue given their respective input bundles. There was no significant difference between public and foreign banks.

In a subsequent paper Ram Mohan and Ray (2005) compare the rates of total factor productivity growth for the three ownership categories of banks over the years 1992-2000. For this they use the Tornqvist and the Malmquist productivity indexes as alternative measures of productivity change. As in the previous paper, they use interest income from loans, investment income, and other income as outputs and interest expenses and operating expenses as inputs. They found that public sector banks outperform private sector banks but do worse that foreign banks if productivity growth is measured by the Malmquist index but foreign banks do worse if one uses the Tornqvist index. The authors conclude that there is no clear evidence that public sector banks performed worse than private or foreign banks in respect of efficiency and productivity growth during the first decade of the post-liberalization era.

It was already pointed out by Ram Mohan and Ray (2004) that Indian banks, especially those in the private sector, had little control over their operating expenses given the difficulty of reducing 
the number of employees. Under these constraints, profit maximization would amount to revenue maximization. Das, Nag, and Ray (2005) examined the efficiency of Indian banks during 19972003 using revenue maximization and profit maximization as alternative objectives of banks. They treated loans, investments, and other income as the three outputs, labor, fixed assets, and borrowed funds as variable inputs, and equity as a quasi-fixed input. They find that the ownership groups do not differ much in respect of either technical efficiency or cost efficiency. However, they differ sharply in respect of revenue efficiency and profit efficiency. An important finding of their study is that if a bank is listed in the Stock Exchange, it exhibits higher profit efficiency. The size of a bank was also found to positively influence profit efficiency.

Ray and Das (2009) provide a more detailed analysis of the data covered in Das, Nag, and Ray (2009). They find that within the category of public sector banks, SBI and its associates show much higher profit efficiency than the other nationalized banks. Foreign banks perform slightly worse than the SBI group but much better than nationalized banks or domestic private banks. There is far less diversity in respect of cost efficiency. In respect of exposure to the Stock Exchange, listed banks operate at a much higher level of profit efficiency than the non-listed banks. For example, in 2003, profit efficiency (measured by the ratio of actual and maximum profit) was $70.7 \%$ for listed banks compared to $58.1 \%$ for non-listed banks. Surprisingly, there was not much difference between the two categories in respect of cost efficiency. In fact, nonlisted banks showed higher cost efficiency than the listed banks in many years. A kernel density analysis of the distribution of profit efficiency in selected years shows that the entire distribution of profit efficiency of domestic banks has shifted outwards over years and that this is driven mainly by the shift in the profit efficiency distribution of public sector banks.

Das and Ghosh (2009) examined the relation between profit efficiency of banks and a number of bank characteristics. Using data for the years 1992-2004 they found that large state-owned banks perform at a higher level of profit efficiency. Also, higher capital adequacy ratio increases profit efficiency. Not surprisingly, a lower percentage of non-performing loans increases profit efficiency.

Sensarma (2006) estimated a cost function using data for the years 1985-2000 to measure cost efficiency and productivity growth of banks of different ownership categories. A surprising finding of the study was that foreign banks performed worse than the public and private banks both in respect of efficiency and productivity growth. 
Shammugam and Das (2004) measured technical efficiency of Indian banks from a frontier production function using data for the years 1992-99. They found that the average levels of technical efficiency were $58.94 \%$ for the SBI group, $52.39 \%$ for foreign banks, $46.31 \%$ for nationalized banks, and $32.1 \%$ for private domestic banks.

Das (2010) used data for the years 1996-2007 to examine the cost efficiency of a panel of 60 Indian banks. The inputs included were borrowed funds, labor, and physical capital. The outputs were loans, investment in securities, and other investments. The study found that average efficiency was the highest for public sector banks (91.1\%). Private domestic banks came second $(90.7 \%)$ and foreign banks came last $(86.6 \%)$.

Ketkar and Ketkar (2008) considered two alternative specifications of the production technology differing in their definition of inputs and outputs. In both models, loans and non-interest income are treated as outputs while equity, total operating expenses, and number of branches are treated as inputs. The difference is that deposits are considered to be output in one version and input in another. They measure efficiency of banks in India for the years 1996-2003. They find that foreign banks are most efficient irrespective of whether deposits are considered output or input. If deposits are considered input, public sector banks perform better than new private banks during 1997-2001. During 2002-04 they lag behind foreign banks and private domestic banks. Also, while efficiency has improved over years for all categories of banks, nationalized banks improved most during the sample period. Their subsequent regression analysis of efficiency scores shows that mandated priority sector lending has hurt the efficiency of public sector banks but branch expansion mandates (for wider geographical area coverage) have not lowered their efficiency.

Wannaiarachchige and Suzuki (2011) measured cost and revenue efficiency of 50 Indian commercial banks for the years 2002-2009. Their study shows that for the entire sample, both cost and revenue efficiencies have declined over the sample period. In respect of cost efficiency foreign banks (89.7\%) and the SBI group (88.3\%) were comparable. Nationalized banks operated at much lower cost efficiency (68\%) and private banks performed the worst (55\%). In respect of revenue efficiency, foreign banks did much better than the SBI group or the other public sector banks. Private banks performed the worst.

Zhao, Casu, and Ferrari (2009) measured both efficiency and productivity growth for a panel of 65 banks for the years 1992-2004. They find that over the entire period public sector banks had the highest average efficiency (88\%), foreign banks were slightly worse (86\%) and domestic private banks were far behind (79\%). It was found that during the initial years foreign banks were 
more efficient than public sector banks but during the later years they were overtaken. Also, the mean efficiency improved for all categories of banks over the years. The entire sample showed evidence of productivity growth of $8 \%$ per year over the period considered.

Sanyal and Shankar (2010) estimated a production function with the sum of loans and deposits as output and Labor, capital, and intermediate inputs (communications expenditure) as inputs. The productivity change is computed from the regression residuals. The authors claim that productivity and productivity growth of Indian private banks were higher than those of either public sector banks or foreign banks. Moreover, superior performance of Indian private banks derives mainly from the higher productivity of old private banks (i.e., those incorporated prior to 1995). This seems to be at odds with what most other studies have concluded.

To summarize the empirical evidence from the various studies reported above, there is a broad agreement that Indian banking reforms have resulted in improved productivity of banks in all ownership categories. Many of the studies find that state-owned banks have operated at at higher levels of efficiency than the domestic private banks and usually above foreign banks as well. The findings are quite sensitive to the choice of inputs and outputs and also to the estimation methodology. Never the less, the broad empirical evidence does not agree with the popular belief, often held as axiomatic truth, that public sector firms governed by bureaucrats protected by attenuated accountability are less efficient than private firms where managers are subject to market discipline. Moreover, foreign firms with better management practices are expected to outperform domestic firms. How can one reconcile the empirical evidence with the prior expectation?

\section{$\underline{\text { 3. Economic Concepts }}$}

\section{Productivity}

In the context of production, the most widely used, and also the easiest to understand, measure of performance is productivity. In the single-output single-input case it, refers to the quantity of output produced per unit of the input. If a firm uses $x_{0}$ units of input $(x)$ to produce $y_{0}$ units of the output $(y)$, its average productivity is

$$
A P_{0}=\frac{y_{0}}{x_{0}}
$$

It should be noted that this average productivity is a descriptive measure of performance without any evaluative content. However, when two input-output bundles $\left(x_{A}, y_{A}\right)$ and $\left(x_{B}, y_{B}\right)$ from two 
firms, $A$ and $B$, are compared the one with a higher average productivity can be regarded as the better performer. Thus, $A$ is more productive than $B$ if

$$
A P_{A}=\frac{y_{A}}{x_{A}}>A P_{B}=\frac{y_{B}}{x_{B}}
$$

Alternatively, we can compute the productivity index of $A$ relative to $B$ as

$$
\pi_{A \mid B}=\frac{A P_{A}}{A P_{B}}=\frac{\frac{y_{A}}{x_{A}}}{\frac{y_{B}}{x_{B}}} .
$$

Thus, $A$ is more productive than $B$ when $\pi_{\mathrm{A} \mid \mathrm{B}}>1$. A different way to measure the same productivity index is

$$
\pi_{A \mid B}=\frac{\frac{y_{A}}{y_{B}}}{\frac{x_{A}}{x_{B}}} .
$$

In the alternative form, the productivity index is the ratio of outputs over the ratio of inputs of the two firms. Even when $A$ produces a smaller output than $B$, if its input is relatively even lower, its productivity turns out to be higher. This is particularly relevant when instead of being two different firms, $A$ and $B$ denote the same firm at two different points in time. A decline in output is quite consistent with an increase in productivity if input declines even further.

But the problem becomes more complicated when the firm uses multiple inputs even when a single output is produced. Suppose that two inputs, $x_{1}$ and $x_{2}$ are used to produce output, $y$. Now we will have two partial average productivities

$$
A P_{1}=\frac{y}{x_{1}} \text { and } A P_{2}=\frac{y}{x_{2}}
$$

instead of a single productivity measure.

Returning to the two firm example, suppose that the input-output bundles of $A$ and $B$ are $\left(x_{1 A}, x_{2 A} ; y_{A}\right)$ and $\left(x_{1 B}, x_{2 B} ; y_{B}\right)$, respectively. The corresponding partial average productivities are

$$
\left(A P_{1 A}=\frac{y_{A}}{x_{1 A}}, A P_{2 A}=\frac{y_{A}}{x_{2 A}}\right) \text { and }\left(A P_{1 B}=\frac{y_{B}}{x_{1 B}}, A P_{2 B}=\frac{y_{B}}{x_{2 B}}\right)
$$

Neither 


$$
\pi_{A \mid B}^{1}=\frac{A P_{1 A}}{A P_{1 B}} \text { nor } \pi_{A \mid B}^{2}=\frac{A P_{2 A}}{A P_{2 B}}
$$

is an appropriate measure of relative productivity. It becomes especially problematic when $A P_{1 A}>A P_{1 B}$ but $A P_{1 A}<A P_{1 B}$. In such cases, we cannot conclude unambiguously which firm has the higher productivity. It may be noted here, in passing, that the practice of making productivity comparison across countries (or regions within a country) or over time by simply using output per worker in manufacturing, yield per acre in agriculture, or business per employee in banking gives an incomplete and often misleading evaluation of relative performance.

A simple way out of this problem is to construct a measure of total factor productivity (TFP) that incorporates both of the partial productivities by taking a (weighted) geometric mean of the partial average productivities. Define

$$
\operatorname{TFP}=\left(A P_{1}\right)^{\beta_{1}}\left(A P_{2}\right)^{\beta_{2}} ; \beta_{1}+\beta_{2}=1 ; \beta_{1}, \beta_{2}>0
$$

Here the weights $\beta_{1}$ and $\beta_{2}$ are selected to reflect the relative importance of the two inputs. Often, $\beta_{1}$ and $\beta_{2}$ reflect the shares of the individual inputs in the total cost (of an average input bundle).

By this definition $\operatorname{TFP}_{A}=\left(A P_{1 A}\right)^{\beta_{1}}\left(A P_{2 A}\right)^{\beta_{2}}=\frac{y_{A}}{x_{1 A}^{\beta_{1}} x_{2 A}^{\beta_{2}}}$. In an analogous way,

$\operatorname{TFP}_{B}=\left(A P_{1 B}\right)^{\beta_{1}}\left(A P_{2 B}\right)^{\beta_{2}}=\frac{y_{B}}{x_{1 B}^{\beta_{1}} x_{2 B}^{\beta_{2}}}$. If we define the aggregate input $X \equiv x_{1}^{\beta_{1}} x_{2}^{\beta_{2}}$, then

$$
T F P_{A}=\frac{y_{A}}{X_{A}} \text { and } T F P_{B}=\frac{y_{B}}{X_{B}}
$$

Hence a total factor productivity index (TFPI) of $A$ relative to $B$ is

$$
\pi=\frac{T F P_{A}}{T F P_{B}}=\frac{\frac{y_{A}}{X_{A}}}{\frac{y_{B}}{X_{B}}}
$$

As in the single input case, we can rewrite the TFPI as

$$
\pi=\frac{T F P_{A}}{T F P_{B}}=\frac{\frac{y_{A}}{X_{A}}}{\frac{y_{B}}{X_{B}}}=\frac{\frac{y_{A}}{y_{B}}}{\frac{X_{A}}{X_{B}}}=\frac{\frac{y_{A}}{y_{B}}}{\left(\frac{x_{1 A}}{x_{1 B}}\right)^{\beta_{1}}\left(\frac{x_{2 A}}{x_{2 B}}\right)^{\beta_{2}}} .
$$

The numerator is merely the ratio of the (single) output quantities. The denominator is the ratio of the aggregated input quantities where the aggregate input is constructed as 


$$
X=x_{1}^{\beta_{1}} x_{2}^{\beta_{2}} .
$$

The ratio $Q_{x}=\left(\frac{x_{1 A}}{x_{1 B}}\right)^{\beta_{1}}\left(\frac{x_{2 A}}{x_{2 B}}\right)^{\beta_{2}}=\frac{X_{A}}{X_{B}}$ is known as the input quantity index.

Finally, when multiple outputs are involved, we need to aggregate the individual outputs of a firm into a single composite output. In the two output case, define the aggregate output as

$$
Y=y_{1}^{\alpha_{1}} y_{2}^{\alpha_{2}} ; \alpha_{1}+\alpha_{2}=1 ; \quad \alpha_{1}, \alpha_{2}>0
$$

Suppose that the output bundles of the two firm are $\left(y_{1 A}, y_{2 A}\right)$ and $\left(y_{1 B}, y_{2 B}\right)$.

Then the aggregated outputs are

$$
Y_{A}=y_{1 A}^{\alpha_{1}} y_{2 A}^{\alpha_{2}} \text { and } Y_{B}=y_{1 B}^{\alpha_{1}} y_{2 B}^{\alpha_{2}} \text {. }
$$

Then the output quantity index of $A$ relative to $B$ is

$$
Q_{y}=\left(\frac{y_{1 A}}{y_{1 B}}\right)^{\alpha_{1}}\left(\frac{y_{2 A}}{y_{2 B}}\right)^{\alpha_{2}}=\frac{Y_{A}}{Y_{B}} .
$$

Hence the TFPI in the multiple-output multiple-input case is

$$
\pi=\frac{\operatorname{TFP}_{A}}{T F P_{B}}=\frac{\frac{Y_{A}}{X_{A}}}{\frac{Y_{B}}{X_{B}}}=\frac{\frac{Y_{A}}{Y_{B}}}{\frac{X_{A}}{X_{B}}}=\frac{Q_{y}}{Q_{x}}=\frac{\left(\frac{y_{1 A}}{y_{1 B}}\right)^{\alpha_{1}}\left(\frac{y_{2 A}}{y_{2 B}}\right)^{\alpha_{2}}}{\left(\frac{x_{1 A}}{x_{1 B}}\right)^{\beta_{1}}\left(\frac{x_{2 A}}{x_{2 B}}\right)^{\beta_{2}}} .
$$

This total factor productivity index is known as the Tornqvist Productivity Index. It may be noted that when instead of two firms we consider the input-output bundles of the same firm at two time points $t=1(A)$ and $t=0(B)$, then the logarithmic differential of TFPI leads to the growth accounting measure of total factor productivity change

$$
\frac{d \pi}{\pi}=\left(\alpha_{1} \frac{d y_{1}}{y_{1}}+\alpha_{2} \frac{d y_{2}}{y_{2}}\right)-\left(\beta_{1} \frac{d x_{1}}{x_{1}}+\beta_{2} \frac{d x_{2}}{x_{2}}\right) .
$$

It should be noted that except in the case of a single output being produced from a single input, the average productivity measure has no physical interpretation. That is because the aggregate input, which is a weighted geometric mean of several inputs measured in different units has no intuitive meaning. The problem is aggravated when multiple outputs are involved. By contrast, in total factor the productivity index, both the numerator and the denominator are unit free and the 
ratio measure how the productivity of the firm has changed from one period to the other. But there is another more important point that needs to be emphasized. Even in the single-input single-output case, the average productivity is a descriptive measure and reveals nothing about the efficiency of the firm. Similarly, the productivity index that compares productivity of two firms or of the same firm in two periods, we cannot conclude anything about the relative efficiency of the two units (or the firm in two periods) from the productivity index. More specifically, an increase in productivity does not by itself signal an increase in efficiency.

\section{Productivity and Efficiency}

Unlike productivity, which is a descriptive measure of performance, efficiency is a normative measure obtained by comparing the actual outcome with a benchmark, which itself might not be an actually observed outcome. The technical efficiency of a firm is measured by comparing its observed output against what is considered to be the maximum producible quantity from the input actually used. This maximum producible quantity is defined by the production function. Consider, for simplicity, the single-input single-output case. The production function can be defined as:

$$
y^{*}=f(x)
$$

where $y^{*}$ is the maximum output producible from input $x$. Now suppose that firm $A$ produces output $y_{A}$ from input $x_{A}$. Then from the production function, the maximum producible quantity is $y_{A}^{*}=f\left(x_{A}\right) \geq y_{A}$. The output-oriented technical efficiency of $A$ is measured as

$$
\tau_{y}^{A}=\frac{y_{A}}{y_{A}^{*}}=\frac{y_{A}}{f\left(x_{A}\right)} .
$$

Now suppose there another firm, $B$, from the same industry that produced output $y_{B}$ from input $x_{B}$. The technical efficiency of $B$ is

$$
\tau_{y}^{B}=\frac{y_{B}}{y_{B}^{*}}=\frac{y_{B}}{f\left(x_{B}\right)} .
$$

It can be seen that technical efficiency of a firm (say $A$ ) can be written as 


$$
\tau_{y}^{A}=\frac{y_{A}}{y_{A}^{*}}=\frac{\frac{y_{A}}{x_{A}}}{\frac{y_{A}^{*}}{x_{A}}}=\frac{A P_{A}}{A P_{A}^{*}} .
$$

That is, technical efficiency is the productivity index of the firm relative to its own efficient projection.

Consider the following decomposition of the productivity index

$$
\pi_{A \mid B}=\frac{A P_{A}}{A P_{B}}=\frac{\frac{y_{A}}{x_{A}}}{\frac{y_{B}}{x_{B}}}=\left[\frac{\frac{y_{A}}{f\left(x_{A}\right)}}{\frac{y_{B}}{f\left(x_{B}\right)}}\right] \cdot\left[\frac{\frac{f\left(x_{A}\right)}{x_{A}}}{\frac{f\left(x_{B}\right)}{x_{B}}}\right]=\frac{\tau_{y}^{A}}{\tau_{y}^{B}} \cdot\left[\frac{\frac{f\left(x_{A}\right)}{x_{A}}}{\frac{f\left(x_{B}\right)}{x_{B}}}\right] .
$$

It is clear that even when $\tau_{y}^{A}>\tau_{y}^{B}, A P_{A}$ can be lower than $A P_{B}$ if the second factor is sufficiently smaller than 1. This second factor is what we can call the returns to scale effect. Note that when the technology exhibits constant returns to scale, average productivity along the production function remains constant. In that case, there are no returns to scale effect because $\frac{f\left(x_{A}\right)}{x_{A}}=\frac{f\left(x_{B}\right)}{x_{B}}$. Otherwise, the two will diverge and if $x_{A}>x_{B}$ and diminishing returns to scale holds at $x_{B}$, $\frac{f\left(x_{A}\right)}{x_{A}}<\frac{f\left(x_{B}\right)}{x_{B}}$. For sufficiently strong diminishing returns, productivity of $A$ may be lower even though it is more efficient.

A further complication arises when the input-output bundles being compared for productivity change relate to the same firm but from two different time periods between which the production function has shifted due to technical change. Suppose that we are comparing the bundle $\left(x_{0}, y_{0}\right)$ from period $t=0$ with the bundle $\left(x_{1} \cdot y_{1}\right)$ from period $t=1$. Assume, further, that between the two periods the production function has changed from $y^{*}=f^{\theta}(x)$ in period 0 to $y^{*}=f^{A}(x)$ in period 1 . Now the productivity index of the same firm in period 1 relative to period 0 is

$$
\pi=\frac{\frac{y_{1}}{x_{1}}}{\frac{y_{0}}{x_{0}}}=\frac{\frac{y_{1}}{f^{1}\left(x_{1}\right)}}{\frac{y_{0}}{f^{0}\left(x_{0}\right)}} \cdot \frac{f^{1}\left(x_{1}\right)}{\frac{x_{1}}{f^{1}\left(x_{0}\right)}} \cdot \frac{f^{1}\left(x_{0}\right)}{x_{0}} .
$$

In this decomposition, the first factor on the right is the change in technical efficiency $\frac{\tau_{y}^{1}}{\tau_{y}^{0}}$, the second factor is the returns to scale effect along the period 1 production function, $f^{d}(x)$, and the last factor is the autonomous shift in the production function from $f^{\theta}(x)$ to $f^{d}(x)$ evaluate at the input level $x_{0}$. 
An alternative decomposition of the same productivity index would be

$$
\pi=\frac{\frac{y_{1}}{x_{1}}}{\frac{y_{0}}{x_{0}}}=\frac{\frac{y_{1}}{f^{1}\left(x_{1}\right)}}{\frac{y_{0}}{f^{0}\left(x_{0}\right)}} \cdot \frac{\frac{f^{0}\left(x_{1}\right)}{x_{1}}}{\frac{f^{0}\left(x_{0}\right)}{x_{0}}} \cdot \frac{f^{1}\left(x_{1}\right)}{f^{0}\left(x_{1}\right)} .
$$

The difference between the two is that in this second version, returns to scale effect is measured along the period- 0 production function while technical change is measured by the shift in the production function at the input level $x_{1}$. Because there is no primary reason to prefer one over the other, we can take the geometric mean of the two to obtain

$$
\pi=(E C) .(S C) .(T C)
$$

where

$$
E C=\frac{\frac{y_{1}}{f^{1}\left(x_{1}\right)}}{\frac{y_{0}}{f^{0}\left(x_{0}\right)}}=\frac{\tau_{y}^{1}}{\tau_{y}^{0}}
$$

measures (technical) efficiency change,

$$
S C=\left[\frac{\frac{f^{0}\left(x_{1}\right)}{x_{1}}}{\frac{f^{0}\left(x_{0}\right)}{x_{0}}} \cdot \frac{\frac{f^{1}\left(x_{1}\right)}{x_{1}}}{\frac{f^{1}\left(x_{0}\right)}{x_{0}}}\right]^{\frac{1}{2}}
$$

measures the returns to scale effect of change in input scale, and

$$
T C=\left[\frac{f^{1}\left(x_{0}\right)}{f^{0}\left(x_{0}\right)} \frac{f^{1}\left(x_{1}\right)}{f^{0}\left(x_{1}\right)}\right]^{\frac{1}{2}}
$$

measure the technical change by the average shift in the production function.

In any empirical application, this three factor decomposition can separate the contribution of each factor as the driving force behind change in total factor productivity over time.

\section{$\underline{\text { Measuring Technical Efficiency with Multiple Inputs and Outputs }}$}

When the firm's production technology involves multiple inputs $x=\left(x_{1}, x_{2}, \ldots, x_{n}\right)$ and multiple outputs , $\quad y=\left(y_{1}, y_{2}, \ldots, y_{m}\right)$ we cannot use a production function explicitly relating the output to inputs. Instead, we need to resort to an implicit function (which is also known as the transformation function) of the form 


$$
F(x, y)=1 .
$$

The production possibility set consists of all input-output bundles $(x, y)$ satisfying

$$
F(x, y) \leq 1
$$

We assume that the value of the function $F(x, y)$ increases when any output increases and fall as any input increases. A bundle $\left(x^{0}, y^{0}\right)$ is technically efficient if $F\left(x^{0}, y^{0}\right)$ equals unity.

When a bundle is not technically efficient, it can be made efficient by altering its inputs and outputs appropriately such that the adjusted input-output bundle becomes technically efficient.

For simplicity, consider the 2-input 2-output case. Suppose that the bundle $\left(x_{1}^{0}, x_{2}^{0} ; y_{1}^{0}, y_{2}^{0}\right)$ is not efficient. To make it efficient we alter it to $\left(x_{1}^{*}, x_{2}^{*} ; y_{1}^{*}, y_{2}^{*}\right)$ where $x_{1}^{*}=\theta_{1} x_{1}^{0}, x_{2}^{*}=\theta_{2} x_{2}^{0}, y_{1}^{*}=\varphi_{1} y_{1}^{0}, y_{2}^{*}=\varphi_{2} y_{2}^{0}$. The bundle $\left(x_{1}^{*}, x_{2}^{*} ; y_{1}^{*}, y_{2}^{*}\right)$ is treated as the efficient projection of the inefficient input-output bundle. Obviously, there will be many different ways to pick the efficient projection. One possible criterion for choosing the reference input outputbundle would be to minimize the function:

$$
\Gamma=\frac{\theta_{1}^{\beta_{1}} \theta_{2}^{\beta_{2}}}{\varphi_{1}^{\alpha_{1}} \varphi_{2}^{\alpha_{2}}}
$$

subject to the constraint

$$
F\left(x_{1}^{*}, x_{2}^{*} ; y_{1}^{*}, y_{2}^{*}\right)=1
$$

where $x_{1}^{*}=\theta_{1} x_{1}^{0}, x_{2}^{*}=\theta_{2} x_{2}^{0}, y_{1}^{*}=\varphi_{1} y_{1}^{0}, y_{2}^{*}=\varphi_{2} y_{2}^{0}$.

It can be easily seen that

$$
\Gamma=\gamma\left(x_{1}^{0}, x_{2}^{0} ; y_{1}^{0}, y_{2}^{0}\right)=\left[\frac{\left(\frac{y_{1}^{0}}{y_{1}^{*}}\right)^{\alpha_{1}}\left(\frac{y_{2}^{0}}{y_{2}^{*}}\right)^{\alpha_{2}}}{\left(\frac{x_{1}^{0}}{x_{1}^{*}}\right)^{\beta_{1}}\left(\frac{x_{2}^{0}}{x_{2}^{*}}\right)^{\beta_{2}}}\right] .
$$

In other words, it is the total factor productivity of the observed input-output bundle relative to the efficient projection. That is, we select the benchmark bundle that maximizes the total factor productivity relative to the observed bundle. As noted before, being the productivity index of the 
observed bundle relative to its own projection, $\Gamma$ is a measure of the overall technical efficiency of the firm. Portela and Thanssoulis (2004) call this efficiency measure the Geometric Distance Function.

When we consider two different input-output bundles $\left(x^{A}, y^{A}\right)$ and $\left(x^{B}, y^{B}\right)$, the TFPI of $A$ relative to $B$ can be shown to be the ratio of their respective generalized technical efficiency measures. (See Ray and Chen (2011) for a proof).

More specifically,

$$
\pi_{A \mid B}=\frac{\left(\frac{y_{1}^{A}}{y_{1}^{B}}\right)^{\alpha_{1}}\left(\frac{y_{2}^{A}}{y_{2}^{B}}\right)^{\alpha_{2}}}{\left(\frac{x_{1}^{A}}{x_{1}^{B}}\right)^{\beta_{1}}\left(\frac{x_{2}^{A}}{x_{2}^{B}}\right)^{\beta_{2}}}=\frac{\gamma\left(x_{1}^{A}, x_{2}^{A} ; y_{1}^{A}, y_{2}^{A}\right)}{\gamma\left(x_{1}^{B}, x_{2}^{B} ; y_{1}^{B}, y_{2}^{B}\right)}
$$

In this discussion so far it has been assumed that firms $A$ and $B$ both have access to the same technology. If the observed input-output bundles are from two different points in time, we may need to consider the possibility of technological change.

Let $\left(x^{0}, y^{0}\right)$ and $\left(x^{1}, y^{1}\right)$ be the input-output bundles of the same firm in periods 0 and 1 , respectively. Further, let the technologies in the two periods be defined by the period-specific transformation functions $F^{0}(x, y)$ and $F^{1}(x, y)$. The generalized efficiency level of the firm needs to be evaluated in light of the contemporaneous technology where as the productivity change is the ratio of the Geometric Distance Function evaluated at the two input-output bundles relative to the same technology. There will therefore be two alternative measures

$$
\pi_{1 \mid 0}^{0}=\frac{\left(\frac{y_{1}^{1}}{y_{1}^{0}}\right)^{\alpha_{1}}\left(\frac{y_{2}^{1}}{y_{2}^{0}}\right)^{\alpha_{2}}}{\left(\frac{x_{1}^{1}}{x_{1}^{0}}\right)^{\beta_{1}}\left(\frac{x_{2}^{1}}{x_{2}^{0}}\right)^{\beta_{2}}}=\frac{\gamma^{0}\left(x_{1}^{A}, x_{2}^{A} ; y_{1}^{A}, y_{2}^{A}\right)}{\gamma^{0}\left(x_{1}^{B}, x_{2}^{B} ; y_{1}^{B}, y_{2}^{B}\right)}
$$

and 


$$
\pi_{1 \mid 0}^{1}=\frac{\left(\frac{y_{1}^{1}}{y_{1}^{0}}\right)^{\alpha_{1}}\left(\frac{y_{2}^{1}}{y_{2}^{0}}\right)^{\alpha_{2}}}{\left(\frac{x_{1}^{1}}{x_{1}^{0}}\right)^{\beta_{1}}\left(\frac{x_{2}^{1}}{x_{2}^{0}}\right)^{\beta_{2}}}=\frac{\gamma^{1}\left(x_{1}^{A}, x_{2}^{A} ; y_{1}^{A}, y_{2}^{A}\right)}{\gamma^{1}\left(x_{1}^{B}, x_{2}^{B} ; y_{1}^{B}, y_{2}^{B}\right)}
$$

Taking the geometric mean of the two we get

$$
\pi_{1 \mid 0}=\frac{\left(\frac{y_{1}^{1}}{y_{1}^{0}}\right)^{\alpha_{1}}\left(\frac{y_{2}^{1}}{y_{2}^{0}}\right)^{\alpha_{2}}}{\left(\frac{x_{1}^{1}}{x_{1}^{0}}\right)^{\beta_{1}}\left(\frac{x_{2}^{1}}{x_{2}^{0}}\right)^{\beta_{2}}}=\left[\frac{\gamma^{1}\left(x_{1}^{1}, x_{2}^{1} ; y_{1}^{1}, y_{2}^{1}\right)}{\gamma^{0}\left(x_{1}^{0}, x_{2}^{0} ; y_{1}^{0}, y_{2}^{0}\right)}\right]\left[\frac{\gamma^{1}\left(x_{1}^{0}, x_{2}^{0} ; y_{1}^{0}, y_{2}^{0}\right)}{\gamma^{0}\left(x_{1}^{0}, x_{2}^{0} ; y_{1}^{0}, y_{2}^{0}\right)} \frac{\gamma^{1}\left(x_{1}^{1}, x_{2}^{1} ; y_{1}^{1}, y_{2}^{1}\right)}{\left.\gamma_{1}^{1}, x_{2}^{1} ; y_{1}^{1}, y_{2}^{1}\right)}\right]^{\frac{1}{2}}
$$

The first factor on the right hand side of the decomposition of TFPI measures the change in efficiency. The second factor a measure of how the transformation function has shifted and reflects technical change.

A final point is to be noted here. This decomposition does not accommodate returns to scale effect separately because it is subsumed under technical efficiency change. The fact is that inputs (and also outputs) are allowed to change at different rates and hence the resulting bundle does not reflect a change in scale. But there is also another aspect of the problem. In the usual input- or output-oriented measurement of technical efficiency, we do not allow outputs to decline or inputs to increase. In the present case, inputs may increase (i.e., a $\theta$ may exceed 1 or a $\varphi$ may be less than 1) so long as the overall value of $\Gamma$ is minimized. This implies a trade off between inputs and outputs, which may be unacceptable to some analysts. In that case the $\theta$ s may all be restricted to be less than or equal to unity and the $\varphi s$ to be greater than or equal to 1 . The restricted projection will not necessarily be the point of maximum total factor productivity. The ratio of maximum productivity with and without these restrictions can be interpreted as a returns to scale effect.

\section{Empirical Analysis of Post-Reform Data}

Productivity measurement in the service sector in general is quite difficult. Unlike in manufacturing, most outputs in the service sector are intangible and are only indirectly measureable. For example, in the airline industry passenger transportation has to be measured by occupied seat-miles flown. Often, the delivery of services requires active participation of the consumer (as in the case of physician's services). In many cases, output is produced on demand only and cannot be stored for future delivery. Finally, due to wide variation in quality, 
quantitative measurement of output can be quite problematic. In the case of banking, an added problem is that there is no universally accepted categorization of inputs and outputs. A typical commercial bank accepts deposits, makes commercial, real estate, and personal loans, makes investments in government securities as well as in private funds, and offers a variety of fee-based financial services. To carry out all these activities, it utilizes labor, physical capital, and IT capital. While labor and capital are universally accepted as inputs and loans, investments, and other services are considered outputs, there is no consensus on whether deposit is an input or an output. This ambiguity follows from two alternative views of the production process in the banking industry. In the so called production approach banks are viewed as providers of services to the two broad categories of its customers, the depositors and the borrowers. In this conceptualization, labor and capital are the inputs and the numbers of deposit and credit transactions are the outputs. Given the lack of information on the numbers of transactions, numbers of the two kinds of accounts are used as measures of outputs. By contrast, in the intermediation approach banks are seen to be intermediaries of funds from savers to investors. Banks collect funds by accepting deposits (and also by borrowing from lenders) and turn them into revenue generating assets like loans and investments. One version of the intermediation approach is the asset approach where the primary focus is on intermediation between depositors and the final users of financial assets of the bank. In this approach, deposits along with labor and capital (both physical and IT) are considered inputs while loans, investments, and financial services are treated as outputs. Other variants of the intermediation approach are the user cost approach where a financial product is classified as an input or an output based on its net contribution to the revenue of the bank, and the value added approach where deposits and loans are treated as outputs due to their significant contribution to the total value added. Of these, the asset approach is the one that is most consistent with the characterization of a bank as a commercial enterprise that incurs costs on inputs to generate revenue from outputs. Apart from deposits and borrowing, another potential source of funds for a bank is its own capital and reserves or equity that should also be counted as an input, especially in the asset approach. It should be noted, however, that compared to the other inputs, a bank has much less flexibility in altering the level of its equity, which is more like a quasi-fixed input in the short run. In the present study, deposits, fixed assets, labor, and equity (capital and reserves) are included as inputs and loans, investments, and other (non-interest) income are considered outputs.

There is another problem with measurement of efficiency in Indian banking. This is because banks of different ownership categories pursue different objectives. It is reasonable to assume that 
foreign and domestic banks in the private sector seek to maximize profit. In the case of public sector banks, the objective is not so clear cut. As already pointed out, banks under government ownership (consisting of the SBI group of banks and the other nationalized banks) are legally required to pursue the social banking objectives of the government. This requires them to direct $40 \%$ of their total advances to the so called priority sector and also invest a minimum required percentage in government securities. At the same time, these banks are expected to remain profitable in order to maintain their economic viability. What is the optimal outcome depends on how the objective function is specified. Because efficiency measurement requires a comparison of the actual outcome with the optimal, the measured level of efficiency of a bank will be sensitive to the choice of a criterion function. One must bear in mind that there is no 'one size fits all' objective function that applies to all banks while evaluating efficiency in Indian banking.

It must be pointed out here that given its dominant position in the Indian banking industry, SBI is likely to unduly influence the performance of public sector banks as a group relative to the other two ownership categories. In the Indian context SBI is a mega bank that by itself accounted for nearly a quarter of the total assets of all the 93 scheduled commercial banks in India in 2000.Even two decades after liberalization and entry deregulation its share of the total assets of scheduled commercial banks in India remained as high as 17\%. Similarly, in 2010 more than a fifth of all employees of scheduled commercial banks in India worked for SBI. For this reason, for deriving the different efficiency measures, SBI was removed from the data set.

\section{Descriptive Measures of Performance: Labor Productivity}

Before we look at the measures of productivity and efficiency obtained from the normative analysis of the data, it is useful to consider some of the commonly used descriptive measures of performance. Three of the most popular measures of productivity in banking are (a) total business (i.e., sum of deposit and credit) per employee, (b) credit-deposit ratio, and (c) intermediation cost. Out of these, business per employee appeals most to common sense because it is a measure of labor productivity when deposit and credit are considered to be the only two outputs. In this sense, it is grounded in the production approach described above.

Table 1 reports the annual averages of business per employee for the sample years by ownership category of banks. The figures reported are lakhs of rupees in constant 1993-94 prices. As expected, foreign banks outperform domestic banks by a large margin. Private domestic banks started below public sector banks but quickly caught up. In 1995 the two groups were at comparable levels. But the very next year there was a spectacular increase in business per 
employee at private banks from Rs. 55 lakhs in 1995 to Rs. 208 lakhs in 1996. For public sector banks the increase was quite marginal. By 2004 the figure had increased to Rs. 286.7 lakhs for private banks. During this period public banks showed a modest gain going up to Rs.139.9 lakhs. The very next year, however, the public sector banks made a spectacular gain and caught up to private banks in just one year. By 2008 they were clearly outperforming the private domestic banks. What the table shows is that all categories of banks improved in terms of business per employee. Foreign banks stayed above both types of domestic banks. Among the domestic banks, private sector banks showed significant improvement much earlier than public banks. But the public sector banks were able to catch up. Better performance of foreign banks can be ascribed to the higher average account balance in these banks which makes it possible to handle the funds with fewer employees. Among the domestic banks, greater emphasis on priority sector lending along with an inability to trim down a surplus labor force in the face of strong labor unions may account for the poorer performance of public sector banks during the earlier years.

Side by side with business per employee one should also look at the credit-deposit ratio. This gives an idea about the composition of 'total business' narrowly defined as above. A bank may achieve the same level of business per employee by increasing deposits and reducing credit by the same amount. However, given that higher deposits entail additional interest expense while increased credit generates additional revenue for the bank, ranking bank productivity by business per employee is somewhat misleading even as a partial measure of productivity. There is another reason why analyzing the credit-deposit ratio is important. It is generally agreed that intermediation of funds from savers to investors is the most important contribution of the banking sector to the overall economic growth. Banerjee, Cole, and Duflo (2004) have argued that Indian banks are under lenders. There are several reasons for this tendency. First, at the institution level, banks are required by law to invest a stipulated percentage of their funds into government securities. Second, at a personal level, bank officials are generally hesitant to approve credit because in case of default by the borrower, integrity of the official authorizing the loan is often called into question. Also, some researchers (e.g. Ketkar and Ketkar, 2007) characterize the tendency to invest more than the required amount of funds into government securities as 'laziness'.

Table 2 reports the average levels of credit-deposit ratio for the three categories of banks for each of the sample years. For the earlier sub-period (1991-2000), the credit-deposit ratio for the foreign banks was 0.98 , which was about twice as high as those of the domestic banks, both public (0.0.48 and private (0.50). But this is the result of the extremely high levels attained by selected 
foreign banks during the years 1997 and 1998. For example, in 1997 the credit-deposit ratio was 85.16 for Krung Thai Bank, 6.82 for Overseas Chinese Bank, and 3.37 for State Bank of Mauritius. Similarly, in 1998 the figures were 16.97 for Krung Thai Bank and 3.23 for Overseas Chinese Bank. A credit-deposit ratio in excess of 1 for a bank implies that the bank is lending out of its own equity and reserve funds. As noted by Ketkar and Ketkar (2007) many smaller foreign banks operating in India are virtually extensions of their own embassies and mainly service the nationals from those countries. In such cases, the amount of credit extended can easily be out of line with the deposit mobilized. If these exceptionally high credit-deposit ratios are excluded for these years, the average credit-deposit ratio for foreign banks would decline from 3.58 to 0.621 in 1997 and from 1.18 to 0.593 in 1998 . This would bring the foreign bank average in line with (although still higher than) the domestic banks. Here again, the evidence is that over the postreform years banks have been increasing credit relative to deposit. One must recognize though that this may have also been driven to a large extent by the increasing demand for credit in a growing economy where the private sector has been gaining in importance due to the overall economic liberalization.

The third indicator of performance often used to compare banks is intermediation cost as a percentage of total assets. Conceptually, it is a somewhat distorted version of what is known as average cost in microeconomics text books. To be precise, average cost is measured by cost per unit of the output produced. If the total asset of a bank is used as proxy for its output and all noninterest expenses as the total cost then intermediation cost as a fraction of its total assets is a crude measure of its average cost. Table 3 shows how the (average) intermediation cost has changed over time for each category of banks. Between 1992 and 2010 average intermediation cost for public sector banks has fallen from $2.6 \%$ of total assets to below $1.5 \%$. Private domestic banks also show a downward trend but the decline was far less pronounced than what was experienced by the public sector banks. Surprisingly, foreign banks showed an initial increase followed by a downward movement in the later years. Consistent with the much higher level of business per employee, the share of personnel cost in the total operating cost has been much lower for foreign banks. In 2000 , staff cost accounted for $71 \%$ of the total operating expenses of public sector banks. For private domestic banks, share of establishment expenses were about $48 \%$. In the case of foreign banks, employee expenses amounted to about 30\%. By 2003, share of labor cost in private banks fell to $35 \%$ but changed little for either public or foreign banks. During the years 2009 and 2010 labor cost accounted for $62 \%$ of total operating expenses for public sector banks. For private and foreign banks, it had increased to $39 \%$ in 2009 and $41 \%$ in 2010 . Computerization 
and much more wide spread use of ATMs by foreign banks (and to some extent by the private banks) account for a greater share of non-labor expenses in total operating costs. Given the asymmetric distribution of branches in rural and semi-urban areas, a substantially higher share of labor cost in total operating expenses of public sector banks is only to be expected. For example, in 2010 more than $55 \%$ of branches of public sector banks were located in rural and semi-urban areas, about $22 \%$ in urban areas, and less than $20 \%$ in metropolitan cities. Private banks had $42 \%$ of their branches in rural and semi-urban areas, 30\% in urban areas, and 28\% in metropolitan cities. By contrast, $77 \%$ of foreign bank branches were in metropolitan cities, $19 \%$ in urban areas and a minimal presence in rural or semi-urban areas. This is reflected in the limited availability of ATMs for public sector banks. In 2010, there were 87 ATMs per 100 branches for public sector banks, 184 ATMs per 100 branches for private banks, and 10 ATMs for every 3 branches for foreign banks. Greater reliance on more sophisticated technology accounts for higher business per employee but greater intermediation cost for foreign banks.

An important development in the second phase of banking reforms that contributed significantly to a marked decline in the share of labor costs in the total operating expenses of public sector banks was the introduction of a voluntary retirement scheme (VRS) for employees in public sector banks in 2000. A report published by the Federation of Indian Chambers of Commerce and Industry (FICCI) on the banking industry estimated that banks in India were overstaffed to the tune of about 35\%. The Finance Ministry estimated that even at the modest rate of Rs 1 Crore of business per employee, there were 59,338 surplus employees in 12 nationalized banks. As banking reforms gathered momentum and government hand outs tended to dry up, it became apparent that banks could no longer afford to carry the excess manpower. Downsizing the workforce in the highly unionized public sector banks was quite a challenge. After a long period of deliberation, in November 1999, the government introduced a voluntary severance package for public sector employees. Between November, 2000 and March 2001 all public sector banks with the lone exception of Corporation Bank introduced a VRS. By March 2001, as many as 100,810 of the 863,117 employees of the 26 public sector banks accepted the offer. This $11 \%$ reduction in the number of employees resulted in a dramatic reduction of labor cost within a year. But there were problems of major disruption of services in the initial period because downsizing was implemented all at once rather than phased in gradually. Rational reallocation of employees across branches was time consuming. Also, many of the departing employees were the more productive and senior workers who were readily absorbed by the new private sector banks. This explains (at least partially) why a marked reduction in the number of employees did not 
immediately translate into a jump in business per employee for these public sector banks. But as the more recent evidence shows, things eventually ironed out and public sector banks emerged out of this process of adjustment successfully with a leaner and more productive work force. Overall, based on all of these performance indicators, one may conclude that all categories of Indian banks have improved labor productivity. Given their greater reliance on labor, public sector banks appear to have benefitted most in this regard.

\section{$\underline{\text { Non Performing Loans }}$}

An important objective of the banking sector reforms, especially those recommended by the Narasimham Committee II, was to restore financial solvency of the public sector banks by addressing the onerous burden of their accumulated non-performing loans and introducing prudential lending norms. Table 4 shows how the proportion of non-performing loans in the total advances of various categories of banks has declined over years. In this regard, it is useful to distinguish between 'old' and 'new' private banks. It may be recalled that by 1980 most of the larger domestic banks were brought under direct government control through nationalization. The smaller domestic banks that remained outside the public sector constituted the 'old private' category. By contrast, the 'new private' ones are the handful of banks that were established in the post reform era. There were 10 new banks formed in the private sector after the 1993 guidelines and 2 new banks after the 2001 revised guidelines. Out of these, four were promoted by financial institutions, one each by conversion of a co-operative bank and a NBFC into commercial banks, and the remaining six by individual banking professionals and an established media house. Out of the four banks promoted by individuals in 1993, only one has survived with muted growth. The experience of the Reserve Bank over these 17 years has been that banks promoted by individuals, though banking professionals, either failed or merged with other banks or had muted growth.

Only those banks that had adequate experience in broad financial sector, financial resources, and trustworthy people, strong and competent managerial support could withstand the rigorous demands of promoting and managing a bank. However, the 'new' private banks had two advantages compared to the public and 'old private' banks. First, starting from scratch they could opt for modern banking technology at the outset. Second, unlike the established banks they did not carry the enormous burden of non-performing loans accumulated over years.

Table 4 shows markedly different time trends in the share of non-performing loans in total advances of different categories of banks. Back in 1992, nearly a quarter of the total loans made by public sector banks were in default. However, there was a steady decline in the share of nonperforming loans over the years. By 2001 it came down to $12.4 \%$ (half of what it was in 1992). It 
went further down to 5.5\% in 2005 and hovered around 2\% in 2009-10. By all accounts, it is a history of remarkable recovery to international standards (or better) from what for all practical purposes was a precipitous risk of insolvency two decades earlier. Both the 'new' private banks and foreign banks had a much lower proportion of non-performing loans. The 'new' private banks performed better than the foreign banks during 1997-2001 but somewhat worse thereafter. Both categories of banks saw an increase in the proportion of non-performing loans up to 2001 but were able to lower it in subsequent years. By 2010, the 'new' private banks outperformed the foreign banks. In the case of 'old' private banks, the share of non-performing loans in 1997 was $10.7 \%$ compared to a $17.8 \%$ share in the case of public banks. By 1999 it worsened to $13.1 \%$ but declined more or less steadily in the subsequent years falling to a low of $2.32 \%$ by 2010 . In sum, the public sector banks performed better than all categories of banks in respect of non-performing loans. It may be noted, in passing, that reduction in non-performing loans was achieved simultaneously with an increase in credit-deposit ratio. This would suggest an improvement in the quality of loans instead of a reduction in the volume of loans (relative to deposits).

\section{Labor Productivity and Efficiency}

There are two main limitations of using the simple arithmetic measure like business per employee as an indicator of either productivity or efficiency. Even if we treat deposits as output and measure total output by the sum of deposits and credit, labor is not the only input in use. A lower share of employee costs in total intermediation costs implies a higher (physical) capital labor ratio for private and foreign banks. A bank with a higher number of ATMs will naturally be able to handle the same volume of business with fewer employees. The right question to ask is whether a bank is producing the maximum amount of business with its existing number of employees and non-labor inputs. One way to answer the question is to focus on the maximum amount of credit that can be offered without changing any other output or input of the bank. The resulting level of business per employee is the right benchmark for comparison with the actual performance of a bank for evaluating its efficiency.

In order to illustrate this point, the input-output data for individual banks from the year 2009 were used to solve the DEA optimization problem where the objective was to maximize the credit output without reducing the any of the other two outputs (investment and fee-based income) and also without increasing any of the inputs (equity, deposits, fixed assets, and labor). The optimal business per employee was computed for each bank by replacing its actual credit by the maximum possible obtained from the DEA solutions. It is obvious that its actual level of credit remains feasible for a bank in the optimization problem. Therefore, the optimal business per 
employee (BPE*) will not be any lower than the actual business per employee $\left(\mathrm{BPE}^{0}\right)$. The ratio of $\mathrm{BPE}^{0}$ to the benchmark $\left(\mathrm{BPE}^{*}\right)$ can be interpreted as one measure of the efficiency of a bank. These efficiency measures for the individual banks are reported in Table 5. Out of the top 15 of the 75 banks ranked in order of actual business per employee in 2009, all except IDBI Bank were foreign banks. But only 6 out of those 14 were generating the maximum amount of business per employee that would be possible from their respective input bundles. For example, Bank of Tokyo-Mitsubishi had actual business of Rs.1,719.42 lakh per employee. But if it operated efficiently (in terms of credit generation), its business per employee could have gone up to Rs 3,289.43 Lakhs. Similarly, Bank of America was actually generating only $79 \%$ of the business per employee that it could have. At the lower end of spectrum, Sonali Bank and American Express Bank (both foreign banks) were operating at full efficiency even though they had the lowest business per employee among all the 75 banks. Business per employee at Standard Chartered Bank (a foreign bank) was more than twice the amount at Lakshmi Vilas Bank (a new private bank). But the former had an efficiency of $68 \%$ while Lakshmi Vilas Bank operated at full efficiency based on this criterion. It should be emphasized that these examples are used only to show that a bank with a higher observed level of business per employee need not be more efficient. The efficiencies reported in Table 5, being essentially one dimensional in nature, are not intended to be interpreted as comprehensive measures of efficiency of these banks.

\section{Overall Measures of Efficiency and Productivity Change: The Normative Analysis}

As explained above, a generalized or overall measure of efficiency should be computed against a benchmark that is Pareto efficient in the sense that there is no room for any net increase in output or a net decrease in input. There, of course, would be many bundles on the frontier of the technology set that meet this Pareto efficiency requirement. For the present study the benchmark selected for any individual bank is one that would lead to the maximum increase in TFP relative to the observed input-output bundle of the bank.

The data used for the empirical analysis is for the years 1992-2009 from an unbalanced panel of banks varying in number between 98 and 74 in different years. As mentioned already, SBI was excluded from the sample because of its extremely large size relative to all other banks. Also, several banks had to be excluded because of negative non-interest income in selected years. The summary statistics of the input-output data are reported for the three ownership categories in Table 6. All variables except labor are measured in lakhs of Indian Rupees at constant 1993-94 prices. Labor is measured by the number of persons employed. As is apparent from Table 6, the 
average public sector bank is much bigger than the private banks and the foreign banks. This is true even when SBI is not included among the public sector banks. On average a public sector bank is over 2.5 times as large as a private bank and more than 9.5 times as large as a foreign bank in terms of deposit or credit. Also, there is greater variability (judged by the coefficient of variation) among foreign and private banks than among the public sector banks.

Table 7 shows the group-wise average levels of generalized Pareto-Koopmans efficiency of the three ownership categories of banks for each of the sample years. Averaged over all years and all banks in the sample, Public sector banks are found to be the most efficient. Foreign banks come second and private banks come last. During the sub-period 1992-2000 (broadly covering the first decade following liberalization) the average levels of efficiency were 0.953 for public sector banks, 0.927 for foreign banks, and 0.853 for private banks. For public sector banks, the average level of efficiency was marginally higher at 0.954 over later years. But in the case of the other two groups, there was substantial decline - down to 0.885 for foreign banks and 0.824 for private domestic banks. In this respect, the present study confirms the broad conclusion reached in the extant literature that on average public sector banks performed at a higher level of technical efficiency that both foreign banks and private domestic banks.

As explained above, technical inefficiency exists when there is room for increasing outputs without increasing inputs, or reducing inputs without reducing outputs, or some combination of both. Given the multiple input, multiple output nature of production in the banking industry, the potential for reduction in aggregate input can be measured by the weighted geometric mean of the potential reduction in the individual inputs. This input contraction factor is a measure of the input-oriented technical efficiency of an individual bank. Similarly, the inverse of output expansion factor obtained in a parallel manner from potential increase in the individual outputs is the output-oriented efficiency. This factorization of the generalized Pareto-Koopmans efficiency provides a broad idea about the relative contribution of the two kinds of inefficiency - presence of surplus inputs and under achievement of potential outputs - to overall inefficiency. Tables 9 and 10 show the year-wise averages of the input contraction factor and the output expansion factor for the different groups of banks. A comparison of the two tables suggests that all categories of banks were more efficient in conserving inputs than in fully attaining their output potential. It can be seen from Table 9 that on average, there was room for reducing inputs by $4.5 \%$ in the public sector banks, $5.1 \%$ in foreign banks, and by $7.3 \%$ in private banks. By contrast, as revealed by Table 10 , there was room to increase output by $12.5 \%$ in the public sector banks, by $18.3 \%$ in private domestic banks, and by $34.1 \%$ in foreign banks. This large output inefficiency is a major reason why foreign banks are found to be less efficient that public sector 
banks. An even further disaggregation shown in Table 11 identifies how much of the total inefficiency comes from each individual input and output. The column marked 'Foreign' shows the average values of the input contraction and output expansion factors when all of the foreign banks in the sample are included. The entry in this column for Loans $\left(\varphi_{1}\right)$ implies that on average foreign banks would be able to lend 8 times as much as they are doing now without reducing any output or decreasing any input. This unrealistic figure is the result of including three individual banks (KBC Bank, Krung Thai Bank, and Oman International Bank) that reported abnormally low credit amounts in selected years. The recomputed averages for the foreign banks excluding these three are reported in the column marked 'Foreign*'). Now the expansion factor for Loans comes down from 8.15 to 2.104, which is in line with what we get for the other groups of banks. This would lower the overall output expansion factor for foreign banks from 1.34 to 1.29.

Given the special interest focused on labor productivity, the year-wise average of the input contraction factor for labor is reported for the different groups of banks separately in Table 11. The average over the entire data period (1992-2009) shows that foreign banks can cut down employment by $13.6 \%$ on average. The comparable figures for public and private banks are $22.6 \%$ and $28.6 \%$ respectively. The percentage of surplus labor was much higher during the initial years for all domestic banks - both public and private. But the voluntary retirement scheme introduced in 2000 seems to have improved labor use efficiency in public sector banks. This is evident from the lower levels of labor inefficiency during the more recent years.

Tables 12, 13, and 14 show, respectively, the annual average rates of TFPG, technical efficiency change, and scale efficiency change for the different ownership groups of banks. Over the entire sample period foreign banks experienced productivity growth at an annual rate of $3 \%$ on average. Private banks came next with an annual growth rate of $0.5 \%$. Public sector banks were the slowest in productivity growth with an annual rate of only $0.1 \%$. There are two main reasons for this lower rate of TFPG for public banks. First, public sector banks had higher total factor productivity than private or foreign banks. Therefore, in a relative sense, there was less room for improvement. Second, the data do not include SBI, the most important bank in this group. All bank groups improved in respect of both technical efficiency and scale efficiency. Table 13 shows that as a group foreign banks experienced an improvement in technical efficiency at the rate of $2.9 \%$ per year. By comparison, domestic private banks improved at a slower rate of $0.6 \%$ annually and public sector banks at an even slower rate of only $0.3 \%$. In respect of scale efficiency, foreign banks again improved much faster (at the rate of $2.2 \%$ per year than) than 
domestic banks. However, scale efficiency of public sector banks increased at a somewhat better rate than those of the private domestic banks.

The data reported in Tables 12-14 hide a puzzle about the implied rate of technical change. As explained above, changes in total factor productivity are caused by changes in technical and scale efficiencies on one hand and by technical change (reflected by shifts in the frontier) on the other. The nonparametric method used in this study allows the frontier to shift at different rates at different data points. Also, both outward shift (implying technical progress) and inward shifts (implying technical regress) are allowed. A numerical measure of the rate of technical change can be obtained from the difference between the rate of TFP change and the sum of the rates of change in technical and scale efficiencies. By this measure, all three types of banks experienced technical regress. The rates of technical regress were $2.1 \%$ per year in the case of foreign banks, $0.6 \%$ for public sector banks, and $0.2 \%$ for private domestic banks. The obvious question at this point is why should there be any technological retrogression following the reforms. That would, indeed, repudiate all the claims made so far about the beneficial impact of liberalization. The most plausible explanation lies in the interpretation of the residual as an index of technical change. After all, an implication of technical progress is that some input-output bundle that was not feasible in the past becomes feasible after the change. Conversely, technical regress would mean that some bundle that was feasible in the past is no longer producible. In a financial service industry like banking where production consists primarily of converting loanable funds into advances and other revenue generating assets, the frontier can move in or out due to changes in the overall economic conditions of the country in different years. Therefore, although computerization and installation of ATMs do push the frontier outwards, demand fluctuations related to macroeconomic factors can push the frontier backwards. One must be careful about interpreting the residual change as technical regress.

\section{Does Foreign ownership of Equity Matter?}

As stated at the very outset, India's banking reforms are nested within an overall package of economy-wide measures of liberalization and globalization. An important component of liberalization is relaxation of entry restrictions against foreign investment side by side with promotion of the private sector within the country. Consistent with this pattern, apart from allowing entry by new private banks, the reforms also permit private equity holding of up to $49 \%$ in public sector banks. Moreover, up to a maximum of $20 \%$ of this private equity can be held by foreign investors - individual or institutional. In the case of private domestic banks, foreign direct 
investment up to a maximum of $75 \%$ of total equity is permitted. It is generally believed that foreign equity participation enhances productivity by introducing international standards of professionalism and improving standards of governance. The greater the share of foreign equity in a bank, the more likely is it to benefit from such influences. Hence, a greater share of foreign equity can be expected to improve productivity. At the same time, judging by all the empirical evidence in the literature, it appears that government ownership (possibly due to economies of scale enjoyed by the public sector banks) has a positive impact on productivity and efficiency. In order to statistically test the effect of foreign equity holding on bank efficiency the 2009 efficiency scores of 47 domestic banks were regressed on an ownership dummy variable, PUBLIC, and another measuring foreign equity share (FOREIGN_SHARE). Ownership dummy variable assumed the value 1 for public sector banks and 0 for private domestic banks. Of the 47 domestic banks in the sample, 26 were in the public sector. As was the case elsewhere in this study, SBI was excluded from the sample. There was considerable variation in foreign equity ownership both among private and public banks. Among the public sector banks, Punjab National Bank with $19.1 \%$ foreign ownership was close to the statutory upper limit of $20 \%$. Several others like Union Bank of India (17.5\%) and Bank of Baroda (17.1\%) were also quite close. At the same time, there were public sector banks with no foreign equity. Among banks in the private sector, IndusInd Bank (68.5\%). ING Vaisya Bank (67.3\%), and ICICI Bank (66.3\%) had the highest percentages of foreign ownership. Only a handful of private banks had no or nominal foreign equity. The estimated regression model is reported in Table 15. All the coefficients were statistically significant. The ownership dummy was positive highly significant showing that the expected efficiency of a bank with no foreign equity would increase from 0.672 if it was in the private sector to 0.912 if it was a public bank. This was what was expected. But the more important finding was that for any ownership type, the efficiency of a domestic bank increases by 0.003 with 1 percent increase in foreign equity share. The $R^{2}$ of the model is a reasonable 0.43 suggesting that the model is adequate.

Although based on a single-year cross section data, this regression, none the less, provides empirical evidence favoring the hypothesis that foreign equity participation has helped to improve efficiency in Indian banking. In that respect it is an important finding.

\section{Productivity and Quality}

An important aspect of productivity that is generally ignored in the banking literature is the quality of service provided to customers. While the quality is an important dimension of output in every industry, it is much more so in banking where every transaction between a customer and an 
employee of the bank is unique and variation in quality can be enormous. Often a greater volume of transactions is accomplished at the expense of the personal service that a customer at the counter deserves. While variability in quality is acknowledged, researchers typically have to rely on customer satisfaction surveys which are quite expensive, not always accurate, and often poorly designed. There is a popular belief that foreign banks offer a better quality of customer service when compared to the bureaucratically run public sector banks or even the private domestic banks. Because providing better quality of service consumes resources (in terms of employee time), one can expect a lower volume of output if a higher standard of quality is to be maintained. A logical implication of this quality-quantity tradeoff is that a bank can improve productivity by lowering quality. It is interesting to empirically investigate whether a higher level of measured efficiency of a bank has in fact been attained by providing a poorer quality of service. One possible way to measure quality of service is by the number of customer complaints against a bank registered with the Banking Ombudsman office. Customer complaints can be divided into two categories - (i) those than relate to deposit or credit accounts and (ii) those that relate to credit or debit cards. The account related complaints typically involve services offered at a branch. By contrast, card related complaints pertain mostly to electronic fund transfers. Two variables, COMPLAINTS_ACCOUNT and COMPLAINTS_CARDS are used to measure levels of consumer dissatisfaction with these two types of services. Based on the data obtained from Report on Trend and Progress of Banking in India 2009-10 (Appendix Table IV.12 pp 181-183) the average numbers of complaints per 100,000 accounts during the year 2009-10 were 6 for public sector banks, 18 for private banks, and 51 for foreign banks. Within the category of private banks, the average numbers were 4 for old private banks and 25 for new private banks. During the same period, the average numbers (per 100,000 accounts) of card related complaints were 7 for public sector banks, 8 for private banks, and 40 for foreign banks. Although based on data from one year only, these numbers challenge the notion of superior quality of service provided at foreign banks. To measure the impact to lower quality on the efficiency score of a bank, an extended regression including these two complaint variables was estimated using the 2009 data. For this regression all 75 observations (including the 28 foreign banks for that year) were used, By definition, foreign equity share was set at $100 \%$ for all of the foreign banks.

The results are shown in Table 16. Estimated coefficients of both of the complaint variables were positive although not significant at the usual $5 \%$ or $10 \%$ levels.. The coefficient of the account related complaints variable has 'p-value' of 0.167 while the other had a ;p-value' of 0.113 . The coefficients of the other variables, the ownership dummy and foreign equity share retained from the previous regression remain highly significant although they are both attenuated in size. The $R^{2}$ 
on the model was 0.232 . Given that it includes both domestic and foreign banks a greater heterogeneity in the data accounts for this lower goodness of fit.

An interesting application of this model would be to make a comparison of quality-adjusted efficiency across the bank groups. The average levels of efficiency predicted by this model would be 0.9396 for public sector banks, 0.7627 for private banks, and 0.8940 for foreign banks, If the private and foreign banks had the same rate of complaints as public sector banks in 2009, then account related complaints would decline by 12 (from 18 to 6) for private banks and by 45 (from 51 to 6) for foreign banks. For card related complaints the corresponding decrease would be 1 for private banks and 33 for foreign banks. In that case, the predicted average efficiency of private domestic banks would fall slightly to 0.7563 . In the case of foreign banks the predicted average efficiency would decline more substantially to 0.8124 . This shows that once adjusted for quality, the difference in efficiency between public and foreign banks in 2009 was greater than what the unadjusted measures suggest.

\section{Direct Comparison of Total Factor Productivity: A Tale of 3 Banks}

All of the results comparing public, private, and foreign banks along different coordinates of performance are reported in terms of group- and year-wise averages in the various tables. There are two main limitations of comparing groups in terms of averages. First, there can be considerable variation within the groups around the respective group means. This, indeed, is true for foreign and domestic banks where outstanding banks coexist side by side with very weak banks. Second, the averages are not weighted by the sizes of individual banks within a group. Hence, a superior performance by a large bank with a major share in the total assets of the group can be offset by a dismal performance of a minor bank within the same group. A better picture can be found in the results reported in Table 16 for individual banks. But even this is not sufficiently informative. In the first place, the data are averaged for unequal numbers of years for different banks. A higher average for a bank that has been around for only a few years is not distinguishable from a comparable average for another bank that has been in the data set for all the 18 years covered by the sample. Also, dynamic measures of performance expressed in terms of annual rates of change fail to discriminate between a bank that has been at the same high level of efficiency in two years and one that has remained unchanged at a low level of efficiency. Finally, the total number of individual banks listed in the table can be overwhelming for the reader looking for a direct comparison between the three different groups of banks. 
In a sense, it is much more informative to directly compare the best banks from the different categories one on one. This also matches the popular approach where the best private bank is pitted against the best public or foreign bank. One can select ICICI Bank among the private banks and HSBC among foreign banks as the iconic banks of their respective categories. Among public sector banks the automatic choice would SBI. We cannot compare the efficiency levels of these banks directly because SBI was deliberately excluded from the normative analysis so that it does not distort the average efficiency of public sector banks as a group. It is possible to compute descriptive measures of total factor productivity index from the weighted quantity ratios of individual outputs and individual inputs of any pair of banks as described in expression (23) above. Moreover, as shown in (24) and (25), this total factor productivity index also shows the ratio of the overall levels of technical efficiency of these to banks.

For this comparison, the input-output bundle of SBI in 1992 was treated as the reference bundle and the input-output quantities of all of the three banks - ICICI Bank, HSBC, and SBI itself - for the years 1996-2009 were used to compute total factor productivity index for these years. An advantage of using this index (which actually is a Tornqvist productivity index) is its multi-lateral applicability. For any bank comparison across years reflects how its TFP has moved over time. In any year, comparison across banks shows how their TFP compare at a given point in time. In creating the index, the weights assigned were 0.71 for deposits, 0.19 to labor and 0.10 to fixed assets (i.e., physical capital). Among outputs, loans and investments were both given $43 \%$ weight while fee based income was assigned $14 \%$ weight. Because the monetary values were all deflated by the wholesale price index (1993-4 as the base), the deflated values were treated as quantities. The TFPI for the individual banks reported in Table 17 clearly reveal the superior productivity levels of both ICICI Bank and HSBC relative to SBI. ICICI Bank emerges as the best performing of the three clearly dominating SBI in every year during 1997-2009. It also outperformed HSBC in most years. On the few occasions where it performed at a lower level than HSBC, the difference was quite small. HSBC had a lower productivity than SBI only in 1997 but thereafter was well ahead in terms of TFP. Looking at the record of SBI over time, there is evidence of productivity decline during the earlier years. In fact, in 1997 TFP at SBI was lower than what it was in 1992 and it continued to decline over the next two years. In 2000 there was a turn around although productivity still remained below the level reached in 1992. Starting from 2001 TFP at SBI took an upward trajectory and continued to grow more or less steadily over the remaining years of the sample.

This simple analysis shows that the best among the private and foreign banks were more productive than the best public banks. In this sense, the popular perception is ultimately validated. 
However, this does not show is that foreign or private banks in general are more efficient than public sector banks. In fact, there is a much greater degree of homogeneity among the public sector banks (excluding SBI) than among private of foreign banks. Therefore superior performance by selected private or foreign bank should not be automatically projected on to the entire group. There are outstanding private or foreign banks. Side by side there are banks operating at very low level of efficiency in those two groups.

\section{A Summary of the Empirical Evidence}

The present paper adds to the accumulated volume of research on the impact of liberalization on productivity and efficiency in Indian banking that already exists in the literature. In that sense, the empirical evidence from this analysis should be integrated with the previous studies. The main findings from this paper can be summarized as follows.

- There has been a general increase in total factor productivity of all categories of banks public, private, and foreign. Rate of productivity growth was higher among foreign banks than domestic banks.

- Improvement in technical efficiency was a main factor behind productivity growth.

- As a group, public sector banks were more efficient that foreign banks. This superior performance of public sector banks was evident despite the fact that SBI, the iconic bank in that category, was excluded from the analysis. Private domestic banks were substantially less efficient than foreign banks.

- In a direct comparison of the three leading banks from the different ownership groups, ICICI Bank from the private domestic category had the highest total factor productivity. HSBC, a major foreign bank, came a close second while SBI was a distant third.

- The government's effort to downsize employment in the public sector banks through a onetime voluntary retirement scheme launched in 2000 seems to have paid off in the form of improved total factor productivity down the road.

- A higher share of foreign ownership of equity has a beneficial impact on the efficiency of a bank. This is true for both private and public sector banks.

- A higher productivity performance based on standard input-output measures of a bank may hide quality-quantity tradeoff. When adjusted for quality (based on the average number of customer complaints registered with the Banking Ombudsman Office) efficiency of foreign banks would be much lower than what was otherwise found for the year 2009. This is in conflict with the popular perception that foreign banks offer a higher quality of customer service. 


\section{Lessons from India's Experience}

Given the increasingly important role that India is poised to assume an emerging giant in the economic landscape of the world, both academics and policymakers have considerable interest in what other developing economies can learn from India's economic reforms in general and banking sector reforms, in particular. The outcome of every social experiment contains both universal features that can be carried over to other situations and specific features that are unique to the context where the experiment was actually carried out. As repeatedly emphasized by the top banking officials and policy experts, India's banking reforms were not prompted by a crisis. Nor were the broad contours of the reforms dictated by any agency providing multi-lateral aid. The reforms were a deliberate and gradualist attempt to allow a greater role for private and foreign banks that would improve efficiency through competition. There was no all out privatization of the public sector banks. However, allowing limited private ownership of the government banks made them accountable to shareholders and subject to market discipline. Going a step beyond limited privatization, the reforms permitted limited foreign equity participation in domestic banks. By 2009, even at SBI, arguably the poster child of public sector banking, $13.8 \%$ of its equity was held by foreign investors (institution and individual). This, by all accounts, is a far cry from the heyday of total government control of banks when employees in a typical branch of a public sector bank acted like a direct government official and treated its customers with the same kind of bureaucratic contempt.

While much of the criticism heaped on India's dysfunctional public sector banks is well deserved, it is seldom recognized that one of the objectives of nationalization of the major private banks was to use them as agents of social change. Much is said about financial repression and preemption of funds enforced through Cash Reserve Requirement and Statutory Lending Requirement. It is seldom recalled that one factor that prompted bank nationalization (especially in 1969) and directed credit requirement was the monopsonistic control on bank credit enjoyed by the major industrial houses that diverted the flow of funds away from projects with high social benefit. India's social banking objective required these public sector banks to create a vast network of rural branches that were seldom economically profitable. There was an inherent conflict between the objectives of commercial profitability on one hand and financial inclusion and universal banking on the other. In light of this, one would naturally make concessions for the non-commercial goals which evaluating the performance of public sector banks in terms of the standard ratio measures like return on equity and profit per employee. However, lack of accountability coupled with job security over years turned these banks into non-performing 
juggernauts. Well protected by militant labor unions bank employees (especially those in clerical positions) could engage in shirking and featherbedding with impunity.

By making room for competition from domestic and foreign banks, the liberalization measures served as a virtual wake up call to complacent public sector banks forcing them to regain economic viability through higher productivity and also to retain business by becoming more sensitive to customer needs. Trimming the workforce through severance incentives proved to be an effective way to improve productivity. Also after an initial infusion of capital into banks that were struggling to survive, the government refused to continue providing life support. Instead, banks were sent to the capital market to raise equity. This, naturally, had a sobering effect on top level management who recognized that their performance would henceforth be under close market scrutiny. There is ample evidence in the published research that banks which are listed in the market were more profit efficient compared to those that were not.

An important feature of the Indian approach was that the social banking objectives were not discarded in order to make room for privatization. Instead of discontinuing the requirement of priority sector lending, the government widened the coverage of the priority sector giving banks a wider choice in meeting their directed credit obligations. Also, banks were given the option to meet their agricultural credit requirements indirectly by lending to specialized credit institutions like National Bank of Agricultural and Rural Development (NABARD). Similarly, a lowering of the Statutory Lending Requirement forced the government to rely more on the securities market to raise the required funds at market determined interest rates. This also released funds for banks to allocate to assets generating higher revenue.

The two major objectives of banking reforms were to secure operational efficiency and to ensure financial solvency. The accumulated burden of non-performing loans pushed many of the public sector banks to the brink of financial insolvency. The new prudential norms consistent with the Basel Accord brought the risk-quality of loans into prominence and a risk-weighted capital adequacy ratio set at $9 \%$ (which is higher than the international norm) signaled the government's priority given to financial soundness of banks. Legislative changes were also introduced to secure creditor's rights and to facilitate recovery of bad loans. While banks o all categories have succeeded in bringing down the proportion of non-performing loans in their total advances, the record is especially remarkable for public sector banks.

While most of the reforms in the banking sector directly affect the public sector banks, it needs to be emphasized that private banks are not allowed a free hand. As stated by Mohan (2004), ownership and governance in private banks is a matter of great importance to the whole population because the owners or shareholders of the banks have only a minor stake and are in a 
position to leverage an enormous volume of other peoples' funds with little risk of personal loss. This grim warning pronounced in 2004 sounds almost prophetic in the aftermath of the worldwide financial crisis. The evidence that unscrupulous bankers and hedge fund managers in the US and major European countries where banks are under private ownership (except when being bailed out by the government) were able to unleash this disaster should give pause to champions of unregulated banking. The new guidelines for private banks require that all shareholding of $5 \%$ or above must meet the 'fit and proper tests' of competence, reputation, tract record, sources of funds, and so on. There were restrictions on shareholding of $10 \%$ or more in any bank by a single entity without prior approval of RBI. Greater transparency and full disclosure are required in the interest of improved corporate governance. Banks along with other financial institutions are brought under supervision of an apex body formed to ensure financial integrity and solvency.

Every country needs to design a structure of its banking industry that fits well within its own overall development strategy. India's dominant public sector within the banking industry is a legacy of a statist development policy that relied on direct public investment for infrastructure and rural development projects that fell below the radar of a profit maximizing private sector. India's banking sector reforms constitute an effort to strike a proper balance between the social banking goals on one hand and cost efficient intermediation of funds from savers to investors on the other. 
Table 1 Business per Employee (Rs. Lakhs at constant 1993-94 price)

\begin{tabular}{|c|c|c|c|}
\hline Year & Public & Private & Foreign \\
\hline 1992 & 45.025 & 33.883 & 391.479 \\
\hline 1993 & 45.238 & 38.634 & 498.810 \\
\hline 1994 & 43.501 & 44.498 & 536.919 \\
\hline 1995 & 50.587 & 55.679 & 536.052 \\
\hline 1996 & 55.046 & 208.815 & 644.426 \\
\hline 1997 & 58.170 & 238.528 & 526.144 \\
\hline 1998 & 65.226 & 263.246 & 531.281 \\
\hline 1999 & 74.689 & 239.026 & 529.656 \\
\hline 2000 & 83.296 & 289.513 & 580.660 \\
\hline 2001 & 100.054 & 263.435 & 643.431 \\
\hline 2002 & 118.088 & 272.047 & 637.460 \\
\hline 2003 & 127.317 & 254.935 & 992.282 \\
\hline 2004 & 139.909 & 268.769 & 637.799 \\
\hline 2005 & 243.594 & 242.086 & 722.970 \\
\hline 2006 & 231.996 & 239.907 & 684.011 \\
\hline 2007 & 256.014 & 252.976 & 736.028 \\
\hline 2008 & 292.868 & 263.546 & 793.990 \\
\hline 2009 & 349.822 & 292.590 & 894.296 \\
\hline \multicolumn{4}{|l|}{ Average } \\
\hline $92-00$ & 57.864 & 156.869 & 530.603 \\
\hline 01-09 & 206.629 & 261.143 & 749.141 \\
\hline 92-09 & 132.247 & 209.006 & 639.872 \\
\hline
\end{tabular}




\begin{tabular}{|c|c|c|c|}
\hline \multicolumn{3}{|c|}{ Table 2 Credit-Deposit Ratio } \\
\hline Year & Public & Private & Foreign \\
\hline 1992 & 0.54 & 0.48 & 0.51 \\
\hline 1993 & 0.51 & 0.47 & 0.52 \\
\hline 1994 & 0.45 & 0.46 & 0.56 \\
\hline 1995 & 0.47 & 0.49 & 0.59 \\
\hline 1996 & 0.47 & 0.64 & 0.75 \\
\hline 1997 & 0.46 & 0.53 & $3.58 *$ \\
\hline 1998 & 0.46 & 0.49 & $1.18 *$ \\
\hline 1999 & 0.45 & 0.47 & 0.57 \\
\hline 2000 & 0.46 & 0.47 & 0.56 \\
\hline 2001 & 0.48 & 0.47 & 0.65 \\
\hline 2002 & 0.50 & 0.49 & 0.73 \\
\hline 2003 & 0.51 & 0.51 & 0.63 \\
\hline 2004 & 0.51 & 0.50 & 0.56 \\
\hline 2005 & 0.56 & 0.59 & 0.57 \\
\hline 2006 & 0.63 & 0.62 & 0.67 \\
\hline 2007 & 0.67 & 0.62 & 0.55 \\
\hline 2008 & 0.68 & 0.65 & 0.64 \\
\hline 2009 & 0.69 & 0.64 & 0.62 \\
\hline $92-00$ & 0.48 & 0.50 & $0.98^{*}$ \\
\hline $01-09$ & 0.58 & 0.56 & 0.62 \\
\hline & 0.53 & 0.53 & 0.80 \\
\hline
\end{tabular}

Note: Figures marked with an asterisk are inflated by a number of outlier observation. 
Table 3 Intermediation Cost (\% of Total Assets)

\begin{tabular}{|c|c|c|c|}
\hline Year & Public & Private & Foreign \\
\hline 1992 & 2.60 & 2.97 & 2.26 \\
\hline 1993 & 2.64 & 2.71 & 2.70 \\
\hline 1997 & 2.88 & 2.36 & 3.04 \\
\hline 1998 & 2.66 & 2.14 & 2.99 \\
\hline 2003 & 2.25 & 1.99 & 2.79 \\
\hline 2004 & 2.20 & 2.01 & 2.76 \\
\hline 2009 & 1.47 & 2.12 & 2.76 \\
\hline 2010 & 1.49 & 1.97 & 2.56 \\
\hline
\end{tabular}

Note: Table 10 of Mohan (2005, p 519) updated. 
Table 4 Non-Performing Loans ( $\%$ of Total Advances)

\begin{tabular}{|c|c|c|c|c|}
\hline Year & Public & Old Private & New Private & Foreign \\
\hline 1994 & 24.80 & $*$ & $*$ & $*$ \\
\hline 1995 & 19.50 & $*$ & $*$ & $*$ \\
\hline 1996 & 18.00 & $*$ & $*$ & $*$ \\
\hline 1997 & 17.80 & 10.70 & 2.60 & 4.30 \\
\hline 1998 & 16.00 & 10.90 & 3.50 & 6.40 \\
\hline 1999 & 15.90 & 13.10 & 6.20 & 7.60 \\
\hline 2000 & 14.00 & 10.80 & 4.10 & 7.00 \\
\hline 2001 & 12.40 & 10.90 & 5.10 & 6.80 \\
\hline 2002 & 11.10 & 11.00 & 8.90 & 5.40 \\
\hline 2003 & 9.40 & 8.90 & 6.70 & 5.30 \\
\hline 2004 & 7.80 & 7.60 & 5.00 & 4.60 \\
\hline 2005 & 5.50 & 6.00 & 3.60 & 2.80 \\
\hline$\ldots$ & $\ldots$ & $\ldots$ & $\ldots$ & $\ldots$ \\
\hline 2009 & 1.97 & 2.36 & 3.05 & 3.80 \\
\hline 2010 & 2.19 & 2.32 & 2.87 & 4.29 \\
\hline
\end{tabular}

Notes: Table 7 of Mohan (2005) updated.

An asterisk indicates that the figure was not compiled. 
Table 5 Actual and Optimal Business Per Employee (Rs Lakhs) 2009 data

\begin{tabular}{|c|c|c|c|}
\hline Bank & bpe0 & bpe* & eff \\
\hline SONALI BANK & 54.13 & 54.13 & 1.00 \\
\hline AMERICAN EXPRESS BANK & 55.24 & 55.24 & 1.00 \\
\hline MASHREQ BANK & 80.84 & 1324.54 & 0.06 \\
\hline AB BANK & 93.20 & 479.16 & 0.19 \\
\hline RATNAKAR BANK & 157.10 & 339.85 & 0.46 \\
\hline CATHOLIC SYRIAN BANK & 157.87 & 302.67 & 0.52 \\
\hline DEVELOPMENT CREDIT BANK & 179.53 & 346.73 & 0.52 \\
\hline BANK OF CEYLON & 191.52 & 619.64 & 0.31 \\
\hline HDFC BANK & 195.63 & 195.63 & 1.00 \\
\hline KOTAK MAHINDRA BANK & 195.70 & 361.98 & 0.54 \\
\hline NAINITAL BANK & 199.81 & 370.47 & 0.54 \\
\hline LAKSHMI VILAS BANK & 219.10 & 219.10 & 1.00 \\
\hline BANK OF RAJASTHAN & 237.73 & 387.92 & 0.61 \\
\hline CITY UNION BANK & 238.27 & 238.27 & 1.00 \\
\hline DHANALAKSHMI BANK & 245.62 & 371.17 & 0.66 \\
\hline UNITED BANK OF INDIA & 252.28 & 339.51 & 0.74 \\
\hline OMAN INTERNATIONAL BANK & 256.51 & 1149.47 & 0.22 \\
\hline STATE BANK OF BIKANER AND JAIPUR & 257.58 & 257.58 & 1.00 \\
\hline CENTRAL BANK OF INDIA & 258.16 & 258.16 & 1.00 \\
\hline BANK OF BAHRAIN AND KUWAIT & 261.30 & 398.03 & 0.66 \\
\hline INDIAN BANK & 262.80 & 481.76 & 0.55 \\
\hline STATE BANK OF MYSORE & 267.31 & 348.32 & 0.77 \\
\hline BANK OF MAHARASHTRA & 268.37 & 268.37 & 1.00 \\
\hline KARUR VYSYA BANK & 273.27 & 413.01 & 0.66 \\
\hline KARNATAKA BANK & 274.08 & 358.41 & 0.76 \\
\hline STATE BANK OF TRAVANCORE & 280.41 & 280.41 & 1.00 \\
\hline SOUTH INDIAN BANK & 281.62 & 374.59 & 0.75 \\
\hline PUNJAB NATIONAL BANK & 283.98 & 283.98 & 1.00 \\
\hline ALLAHABAD BANK & 298.35 & 402.13 & 0.74 \\
\hline
\end{tabular}




\begin{tabular}{|c|c|c|c|}
\hline CHINATRUST COMMERCIAL BANK & 299.67 & 1508.36 & 0.20 \\
\hline INDIAN OVERSEAS BANK & 300.14 & 347.69 & 0.86 \\
\hline PUNJAB AND SIND BANK & 300.58 & 348.82 & 0.86 \\
\hline ING VYSYA BANK & 303.49 & 359.88 & 0.84 \\
\hline JAMMU AND KASHMIR BANK & 303.76 & 411.63 & 0.74 \\
\hline UCO BANK & 304.00 & 304.00 & 1.00 \\
\hline DENA BANK & 307.18 & 342.12 & 0.90 \\
\hline FEDERAL BANK & 308.32 & 458.29 & 0.67 \\
\hline ANDHRA BANK & 310.19 & 311.22 & 1.00 \\
\hline CANARA BANK & 317.75 & 317.75 & 1.00 \\
\hline VIJAYA BANK & 319.18 & 381.24 & 0.84 \\
\hline SYNDICATE BANK & 335.84 & 335.84 & 1.00 \\
\hline STATE BANK OF INDORE & 341.22 & 341.22 & 1.00 \\
\hline UNION BANK OF INDIA & 347.60 & 380.87 & 0.91 \\
\hline BANK OF INDIA & 359.33 & 359.33 & 1.00 \\
\hline STATE BANK OF HYDERABAD & 363.82 & 363.82 & 1.00 \\
\hline STATE BANK OF PATIALA & 387.97 & 387.97 & 1.00 \\
\hline BANK OF BARODA & 391.58 & 391.58 & 1.00 \\
\hline INDUSIND BANK & 394.25 & 441.75 & 0.89 \\
\hline CORPORATION BANK & 421.49 & 421.49 & 1.00 \\
\hline AXIS BANK & 427.65 & 427.65 & 1.00 \\
\hline SBI COMMERCIAL AND INTL & 451.43 & 964.34 & 0.47 \\
\hline STANDARD CHARTERED BANK & 463.21 & 677.53 & 0.68 \\
\hline KRUNG THAI BANK & 474.93 & 474.92 & 1.00 \\
\hline ORIENTAL BANK OF COMMERCE & 482.29 & 549.50 & 0.88 \\
\hline YES BANK & 485.74 & 485.74 & 1.00 \\
\hline HONGKONG AND SHANGHAI BANK & 486.15 & 486.15 & 1.00 \\
\hline ABN AMRO BANK & 547.37 & 547.37 & 1.00 \\
\hline DEUTSCHE BANK & 558.41 & 738.11 & 0.76 \\
\hline BARCLAYS BANK & 600.38 & 780.15 & 0.77 \\
\hline ICICI BANK & 614.41 & 614.41 & 1.00 \\
\hline ABU DHABI COMMERCIAL BANK & 698.54 & 1474.70 & 0.47 \\
\hline
\end{tabular}




\begin{tabular}{|l|c|c|c|}
\hline SOCIETE GENERALE & 780.46 & 1448.43 & 0.54 \\
\hline MIZUHO CORPORATE BANK & 913.35 & 2079.88 & 0.44 \\
\hline CITIBANK & 968.99 & 968.99 & 1.00 \\
\hline SHINHAN BANK & 1032.13 & 2427.76 & 0.43 \\
\hline IDBI BANK & 1076.00 & 1076.00 & 1.00 \\
\hline STATE BANK OF MAURITIUS & 1090.62 & 2244.88 & 0.49 \\
\hline BNP PARIBAS & 1204.16 & 1707.83 & 0.71 \\
\hline DBS BANK & 1320.83 & 1320.83 & 1.00 \\
\hline BANK OF AMERICA & 1389.18 & 1760.42 & 0.79 \\
\hline BANK OF TOKYO-MITSUBISHI & 1719.42 & 3289.43 & 0.52 \\
\hline J P MORGAN CHASE BANK & 1864.36 & 1864.36 & 1.00 \\
\hline BANK OF NOVA SCOTIA & 2341.46 & 2341.46 & 1.00 \\
\hline CALYON BANK & 2414.30 & 2414.30 & 1.00 \\
\hline ANTWERP DIAMOND BANK & 2879.61 & 2879.61 & 1.00 \\
\hline
\end{tabular}


Table 6 Summary Statistics

\begin{tabular}{|l|l|c|c|c|c|c|c|c|c|}
\hline & & Equity & Deposits & Fixed Assets & Labor & Credit & Investments & Other Income \\
\hline Public & Mean & 107202.26 & 1704200.81 & 20469.99 & 23049.89 & 972507.86 & 646940.85 & 23477.60 \\
\hline & Std Dev & 102539.62 & 1513798.28 & 22793.68 & 16422.78 & 1030719.61 & 497420.95 & 20999.38 \\
\hline Private & Mean & 40151.77 & 449610.91 & 8814.59 & 3025.47 & 273768.94 & 172579.04 & 9147.98 \\
\hline & Std Dev & 160675.35 & 1289268.22 & 26475.91 & 4710.51 & 904594.46 & 479126.71 & 32568.22 \\
\hline & & & & & & & \\
\hline
\end{tabular}


Table 7 Pareto Koopmans Efficiency

\begin{tabular}{|c|c|c|c|}
\hline Year & Public & Private & Foreign \\
\hline 1992 & 0.939 & 0.833 & 0.972 \\
\hline 1993 & 0.948 & 0.844 & 0.946 \\
\hline 1994 & 0.920 & 0.824 & 0.947 \\
\hline 1995 & 0.957 & 0.848 & 0.949 \\
\hline 1996 & 0.965 & 0.863 & 0.929 \\
\hline 1997 & 0.962 & 0.837 & 0.892 \\
\hline 1998 & 0.972 & 0.908 & 0.938 \\
\hline 1999 & 0.959 & 0.842 & 0.893 \\
\hline 2000 & 0.956 & 0.878 & 0.875 \\
\hline 2001 & 0.941 & 0.830 & 0.875 \\
\hline 2002 & 0.959 & 0.858 & 0.847 \\
\hline 2003 & 0.973 & 0.875 & 0.889 \\
\hline 2004 & 0.979 & 0.871 & 0.901 \\
\hline 2005 & 0.969 & 0.800 & 0.927 \\
\hline 2006 & 0.933 & 0.801 & 0.859 \\
\hline 2007 & 0.939 & 0.808 & 0.896 \\
\hline 2008 & 0.953 & 0.792 & 0.889 \\
\hline 2009 & 0.940 & 0.779 & 0.886 \\
\hline Average & 0.953 & |0.838 & 0.906 \\
\hline
\end{tabular}


Table 8a Input Contraction factor

\begin{tabular}{|c|c|c|c|}
\hline Year & Public & Private & Foreign \\
\hline 1992 & 0.982 & 0.970 & 0.989 \\
\hline 1993 & 0.984 & 0.956 & 0.974 \\
\hline 1994 & 0.989 & 0.974 & 0.961 \\
\hline 1995 & 0.966 & 0.946 & 0.922 \\
\hline 1996 & 0.894 & 0.879 & 0.958 \\
\hline 1997 & 0.964 & 0.853 & 0.892 \\
\hline 1998 & 0.990 & 0.942 & 0.974 \\
\hline 1999 & 0.929 & 0.906 & 0.918 \\
\hline 2000 & 0.962 & 0.932 & 0.944 \\
\hline 2001 & 0.961 & 0.934 & 0.952 \\
\hline 2002 & 0.937 & 0.919 & 0.936 \\
\hline 2003 & 0.936 & 0.938 & 0.945 \\
\hline 2004 & 0.965 & 0.931 & 0.967 \\
\hline 2005 & 0.970 & 0.940 & 0.968 \\
\hline 2006 & 0.960 & 0.899 & 0.939 \\
\hline 2007 & 0.959 & 0.942 & 0.940 \\
\hline 2008 & 0.915 & 0.859 & 0.978 \\
\hline 2009 & 0.923 & 0.894 & 0.934 \\
\hline Average & 0.955 & 0.923 & 0.949 \\
\hline
\end{tabular}


Table 9 Output Expansion Factor

\begin{tabular}{|c|c|c|c|}
\hline Year & Public & Private & Foreign \\
\hline 1992 & 1.053 & 1.175 & 1.020 \\
\hline 1993 & 1.089 & 1.172 & 1.086 \\
\hline 1994 & 1.291 & 1.293 & 1.054 \\
\hline 1995 & 1.203 & 1.224 & 1.087 \\
\hline 1996 & 1.153 & 1.213 & 1.212 \\
\hline 1997 & 1.120 & 1.181 & 1.259 \\
\hline 1998 & 1.106 & 1.086 & 1.111 \\
\hline 1999 & 1.168 & 1.189 & 1.189 \\
\hline 2000 & 1.134 & 1.139 & 1.299 \\
\hline 2001 & 1.154 & 1.213 & 1.314 \\
\hline 2002 & 1.132 & 1.148 & 2.428 \\
\hline 2003 & 1.075 & 1.137 & 1.239 \\
\hline 2004 & 1.090 & 1.121 & 1.300 \\
\hline 2005 & 1.084 & 1.226 & 1.247 \\
\hline 2006 & 1.122 & 1.169 & 1.339 \\
\hline 2007 & 1.114 & 1.211 & 1.745 \\
\hline 2008 & 1.072 & 1.161 & 1.684 \\
\hline 2009 & 1.094 & 1.241 & 1.529 \\
\hline Average & 1.125 & 1.183 & 1.341 \\
\hline
\end{tabular}


Table 10 Specific Input/Output Efficiency Factors

\begin{tabular}{|c|c|c|c|c|c|}
\hline & & Public & Private & Foreign & Foreign* \\
\hline Deposits & $\theta 1$ & 0.983 & 0.986 & 0.994 & 0.994 \\
\hline Labor & $\theta 2$ & 0.801 & 0.666 & 0.771 & 0.781 \\
\hline Capital & $\theta 3$ & 0.774 & 0.720 & 0.862 & 0.862 \\
\hline Loans & 1 & 1.071 & 1.085 & 8.185 & 1.253 \\
\hline Investment & 2 & 1.051 & 1.136 & 1.199 & 1.191 \\
\hline Others & 3 & 1.870 & 2.334 & 2.104 & 1.901 \\
\hline
\end{tabular}


Table 11 Labor Contraction Factor

\begin{tabular}{|c|c|c|c|}
\hline Year & Public & Private & Foreign \\
\hline 1992 & 0.834 & 0.473 & 0.935 \\
\hline 1993 & 0.569 & 0.411 & 0.916 \\
\hline 1994 & 0.771 & 0.838 & 0.927 \\
\hline 1995 & 0.385 & 0.688 & 0.803 \\
\hline 1996 & 0.513 & 0.662 & 0.882 \\
\hline 1997 & 0.728 & 0.668 & 0.810 \\
\hline 1998 & 0.870 & 0.728 & 0.853 \\
\hline 1999 & 0.820 & 0.812 & 0.910 \\
\hline 2000 & 0.697 & 0.628 & 0.848 \\
\hline 2001 & 0.744 & 0.781 & 0.862 \\
\hline 2002 & 0.883 & 0.828 & 0.840 \\
\hline 2003 & 0.941 & 0.873 & 0.793 \\
\hline 2004 & 0.890 & 0.839 & 0.832 \\
\hline 2005 & 0.890 & 0.882 & 0.917 \\
\hline 2006 & 0.829 & 0.759 & 0.853 \\
\hline 2007 & 0.857 & 0.815 & 0.925 \\
\hline 2008 & 0.780 & 0.508 & 0.822 \\
\hline 2009 & 0.928 & 0.667 & 0.833 \\
\hline Average & 0.774 & 0.714 & 0.864 \\
\hline
\end{tabular}


Table 12 Annual Average Rates of TFPG

\begin{tabular}{|c|c|c|c|}
\hline Year & Public & Private & Foreign \\
\hline 1993 & -0.027 & -0.004 & -0.065 \\
\hline 1994 & -0.122 & -0.049 & 0.010 \\
\hline 1995 & 0.031 & 0.035 & -0.010 \\
\hline 1996 & -0.004 & -0.043 & 0.078 \\
\hline 1997 & 0.093 & -0.006 & 0.017 \\
\hline 1998 & 0.058 & 0.225 & 0.357 \\
\hline 1999 & -0.098 & -0.109 & -0.078 \\
\hline 2000 & 0.057 & 0.088 & -0.034 \\
\hline 2001 & -0.004 & -0.055 & 0.046 \\
\hline 2002 & -0.020 & 0.039 & 0.104 \\
\hline 2003 & 0.068 & 0.043 & 0.032 \\
\hline 2004 & 0.019 & 0.001 & 0.059 \\
\hline 2005 & 0.002 & -0.064 & 0.010 \\
\hline 2006 & -0.032 & 0.011 & -0.076 \\
\hline 2007 & 0.013 & 0.013 & 0.016 \\
\hline 2008 & -0.016 & -0.044 & 0.063 \\
\hline 2009 & 0.005 & 0.000 & -0.015 \\
\hline Average & 0.001 & 0.005 & 0.030 \\
\hline
\end{tabular}


Table 13 Annual Average Rates of Technical Efficiency Change

\begin{tabular}{|c|c|c|c|}
\hline Year & Public & Private & Foreign \\
\hline 1993 & 0.014 & 0.016 & -0.027 \\
\hline 1994 & -0.026 & -0.018 & -0.002 \\
\hline 1995 & 0.048 & 0.046 & 0.006 \\
\hline 1996 & 0.011 & 0.054 & 0.022 \\
\hline 1997 & -0.007 & -0.025 & 0.058 \\
\hline 1998 & 0.016 & 0.098 & 0.089 \\
\hline 1999 & -0.012 & -0.071 & -0.026 \\
\hline 2000 & -0.001 & 0.055 & -0.023 \\
\hline 2001 & -0.015 & -0.057 & 0.060 \\
\hline 2002 & 0.022 & 0.032 & 0.045 \\
\hline 2003 & 0.015 & 0.029 & 0.026 \\
\hline 2004 & 0.008 & -0.004 & 0.037 \\
\hline 2005 & -0.008 & -0.058 & 0.005 \\
\hline 2006 & -0.039 & -0.001 & -0.085 \\
\hline 2007 & 0.011 & 0.000 & 0.252 \\
\hline 2008 & 0.018 & -0.003 & 0.027 \\
\hline 2009 & -0.012 & 0.004 & 0.027 \\
\hline Average & 0.003 & 0.006 & 0.029 \\
\hline
\end{tabular}


Table 14 Annual Average Rates of Scale Efficiency Change

\begin{tabular}{|c|c|c|c|}
\hline Year & Public & Private & Foreign \\
\hline 1993 & -0.04 & -0.018 & -0.038 \\
\hline 1994 & -0.1 & -0.032 & 0.014 \\
\hline 1995 & -0.016 & -0.01 & -0.015 \\
\hline 1996 & -0.013 & -0.081 & 0.08 \\
\hline 1997 & 0.102 & 0.025 & 0.007 \\
\hline 1998 & 0.041 & 0.116 & 0.266 \\
\hline 1999 & -0.084 & -0.036 & -0.028 \\
\hline 2000 & 0.061 & 0.04 & -0.009 \\
\hline 2001 & 0.102 & 0.003 & 0.022 \\
\hline 2002 & -0.039 & 0.008 & 0.083 \\
\hline 2003 & 0.051 & 0.013 & 0.002 \\
\hline 2004 & 0.012 & 0.006 & 0.026 \\
\hline 2005 & 0.01 & -0.005 & 0 \\
\hline 2006 & 0.009 & 0.015 & 0.015 \\
\hline 2007 & 0.001 & 0.014 & -0.056 \\
\hline 2008 & -0.032 & -0.038 & 0.055 \\
\hline 2009 & 0.018 & -0.003 & -0.045 \\
\hline Average & 0.005 & 0.001 & 0.022 \\
\hline
\end{tabular}


Table 15 Regression of 2009 Efficiency of Domestic Banks: Model 1

\begin{tabular}{|c|c|c|c|c|c|}
\hline \multicolumn{6}{|c|}{$\begin{array}{l}\text { Variable } \\
\text { Dependent: Eff2009 }\end{array}$} \\
\hline \multicolumn{6}{|l|}{ Independent } \\
\hline \multirow{4}{*}{\multicolumn{2}{|c|}{$\begin{array}{l}\text { Constant } \\
\text { PUBLIC } \\
\text { FOREIGN_SHARE }\end{array}$}} & Coefficient & std. err. & t-ratio & p-value \\
\hline & & 0.6726 & 0.0419 & 16.03 & $<0.0001$ \\
\hline & & 0.2405 & 0.0416 & 5.78 & $<0.0001$ \\
\hline & & 0.0033 & 0.001 & 3.12 & 0.0032 \\
\hline $\mathrm{R}^{2}$ & 0.4338 & $\mathrm{~N}=47$ & & & \\
\hline $\bar{R}^{2}$ & 0.4081 & & & & \\
\hline
\end{tabular}


Table 16 Regression of 2009 Efficiency of Domestic Banks: Model 2

\begin{tabular}{|c|c|c|c|c|c|}
\hline $\begin{array}{l}\text { Variable } \\
\text { Dependent: Eff2009 }\end{array}$ & & & & & \\
\hline Independent & & & & & \\
\hline & & Coefficient & std. err. & t-ratio & $\mathrm{p}$-value \\
\hline Constant & & 0.7090 & 0.0495 & 14.3116 & 0.0000 \\
\hline PUBLIC & & 0.2059 & 0.0553 & 3.7227 & 0.0004 \\
\hline FOREIGN_SHARE & & 0.0014 & 0.0006 & 2.2528 & 0.0274 \\
\hline CONPLAINTS_ACCOUNTS & & 0.0004 & 0.0003 & 1.3954 & 0.1673 \\
\hline COMPLAINTS_CARDS & & 0.0020 & 0.0012 & 1.6052 & 0.1130 \\
\hline $\mathrm{R}^{2}$ & 0.232 & $\mathrm{~N}-75$ & & & \\
\hline $\bar{R}^{2}$ & 0.188 & & & & \\
\hline
\end{tabular}


_Table 17 Bank-wise Annual Averages of TFP Growth, Technical Efficiency Change, and Scale Efficiency Change

\begin{tabular}{|c|c|c|c|}
\hline Name & TFPG & TE Change & SE Change \\
\hline STATE BANK OF BIKANER AND JAIPUR & 0.007 & 0.006 & 0.000 \\
\hline STATE BANK OF HYDERABAD & 0.002 & 0.000 & 0.001 \\
\hline STATE BANK OF INDORE & 0.001 & 0.001 & 0.000 \\
\hline STATE BANK OF MYSORE & -0.015 & -0.015 & 0.000 \\
\hline STATE BANK OF PATIALA & 0.003 & 0.002 & 0.002 \\
\hline STATE BANK OF SAURASHTRA & -0.010 & -0.009 & 0.001 \\
\hline STATE BANK OF TRAVANCORE & 0.000 & 0.000 & 0.000 \\
\hline ALLAHABAD BANK & 0.006 & 0.014 & -0.006 \\
\hline ANDHRA BANK & 0.009 & 0.012 & -0.004 \\
\hline BANK OF BARODA & -0.007 & 0.000 & -0.007 \\
\hline BANK OF INDIA & -0.010 & 0.001 & -0.011 \\
\hline BANK OF MAHARASHTRA & 0.017 & 0.011 & 0.006 \\
\hline CANARA BANK & -0.010 & 0.002 & -0.011 \\
\hline CENTRAL BANK OF INDIA & 0.008 & 0.006 & 0.000 \\
\hline CORPORATION BANK & 0.014 & 0.018 & -0.004 \\
\hline DENA BANK & 0.003 & 0.000 & 0.006 \\
\hline IDBI BANK & -0.200 & -0.200 & -0.200 \\
\hline INDIAN BANK & -0.014 & -0.011 & -0.004 \\
\hline INDIAN OVERSEAS BANK & 0.007 & 0.001 & 0.006 \\
\hline ORIENTAL BANK OF COMMERCE & 0.000 & 0.008 & -0.006 \\
\hline PUNJAB AND SIND BANK & 0.013 & 0.007 & 0.005 \\
\hline PUNJAB NATIONAL BANK & -0.010 & 0.000 & -0.010 \\
\hline SYNDICATE BANK & 0.012 & 0.006 & 0.005 \\
\hline UCO BANK & 0.010 & 0.001 & 0.008 \\
\hline UNION BANK OF INDIA & -0.003 & 0.003 & -0.001 \\
\hline UNITED BANK OF INDIA & 0.006 & -0.004 & 0.013 \\
\hline VIJAYA BANK & 0.001 & 0.006 & 0.005 \\
\hline AXIS BANK & 0.033 & 0.030 & 0.001 \\
\hline BANK OF MADURA & -0.015 & 0.002 & 0.002 \\
\hline
\end{tabular}




\begin{tabular}{|c|c|c|c|}
\hline BANK OF PUNJAB & -0.034 & -0.051 & 0.016 \\
\hline Name & TFPG & TE Change & SE Change \\
\hline BANK OF RAJASTHAN & 0.031 & 0.028 & 0.002 \\
\hline BAREILLY CORPORATION BANK & 0.083 & 0.082 & 0.000 \\
\hline BENARES STATE BANK & 0.004 & 0.023 & 0.005 \\
\hline BHARAT OVERSEAS BANK & -0.009 & -0.009 & 0.000 \\
\hline CATHOLIC SYRIAN BANK & 0.003 & 0.004 & 0.000 \\
\hline CENTURION BK OF PUNJAB & 0.026 & 0.037 & -0.007 \\
\hline CITY UNION BANK & 0.004 & 0.004 & 0.000 \\
\hline DEVELOPMENT CREDIT BANK & 0.034 & 0.011 & 0.014 \\
\hline DHANALAKSHMI BANK & 0.001 & 0.000 & 0.000 \\
\hline FEDERAL BANK & 0.008 & 0.006 & 0.000 \\
\hline GANESH BANK OF KURUNDWAD & -0.039 & -0.028 & -0.003 \\
\hline GLOBAL TRUST BANK & 0.010 & 0.003 & 0.008 \\
\hline HDFC BANK & 0.018 & 0.016 & 0.003 \\
\hline ICICI BANK & 0.009 & 0.013 & -0.006 \\
\hline IDBI BANK & 0.017 & 0.009 & 0.013 \\
\hline INDUSIND BANK & -0.019 & -0.021 & 0.002 \\
\hline ING VYSYA BANK & 0.016 & 0.016 & 0.000 \\
\hline JAMMU AND KASHMIR BANK & -0.019 & -0.015 & 0.000 \\
\hline KARNATAKA BANK & 0.009 & 0.004 & 0.003 \\
\hline KARUR VYSYA BANK & 0.008 & 0.007 & 0.004 \\
\hline KOTAK MAHINDRA BANK & 0.042 & 0.035 & 0.006 \\
\hline LAKSHMI VILAS BANK & 0.001 & 0.001 & 0.005 \\
\hline LORD KRISHNA BANK & 0.006 & 0.006 & 0.003 \\
\hline NAINITAL BANK & 0.016 & 0.002 & 0.033 \\
\hline NEDUNGADI BANK & 0.030 & 0.029 & 0.000 \\
\hline PUNJAB CO-OPERATIVE BANK & -0.046 & 0.000 & -0.046 \\
\hline RATNAKAR BANK & -0.013 & -0.006 & 0.005 \\
\hline SANGLI BANK & 0.024 & 0.024 & 0.001 \\
\hline SBI COMMERCIAL AND INTL & 0.018 & -0.008 & 0.024 \\
\hline
\end{tabular}




\begin{tabular}{|c|c|c|c|}
\hline SOUTH INDIAN BANK & -0.003 & -0.003 & 0.000 \\
\hline TAMILNAD MERCANTILE BANK & 0.021 & 0.016 & 0.004 \\
\hline Name & TFPG & TE Change & SE Change \\
\hline UNITED WESTERN BANK & 0.018 & 0.015 & 0.004 \\
\hline VYSYA BANK & 0.015 & 0.006 & 0.017 \\
\hline YES BANK & 0.012 & 0.015 & -0.003 \\
\hline AB BANK & 0.117 & 0.041 & 0.135 \\
\hline ABN AMRO BANK & 0.012 & 0.005 & 0.008 \\
\hline ABU-DHABI COMMERCIAL BANK & -0.006 & 0.031 & 0.032 \\
\hline AMERICAN EXPRESS BANK & 0.007 & 0.000 & 0.007 \\
\hline ANTWERP DIAMOND BANK & 0.000 & 0.000 & 0.000 \\
\hline BANK INTERNATIONAL INDONESIA & 0.031 & 0.005 & 0.124 \\
\hline BANK MUSCAT INTERNATIONAL & 0.435 & 0.442 & -0.011 \\
\hline BANK OF AMERICA & -0.009 & 0.000 & -0.009 \\
\hline BANK OF BAHRAIN AND KUWAIT & -0.009 & -0.007 & 0.000 \\
\hline BANK OF CEYLON & 0.013 & 0.013 & 0.010 \\
\hline BANK OF NOVA SCOTIA & 0.000 & 0.000 & 0.000 \\
\hline BANK OF TOKYO & -0.030 & -0.018 & -0.010 \\
\hline BANK OF TOKYO-MITSUBISHI & 0.016 & 0.036 & -0.027 \\
\hline BARCLAYS BANK & 0.104 & 0.119 & -0.006 \\
\hline BNP PARIBAS & 0.012 & 0.011 & -0.001 \\
\hline BRITISH BANK OF MIDDLE EAST & 0.009 & 0.000 & 0.009 \\
\hline CALYON BANK & 0.000 & 0.000 & 0.000 \\
\hline CHINATRUST COMMERCIAL BANK & 0.132 & 0.110 & 0.020 \\
\hline CITIBANK & -0.001 & 0.000 & -0.001 \\
\hline COMMERZ BANK & 0.312 & 0.476 & -0.008 \\
\hline CREDIT AGRICOLE INDOSUEZ & 0.016 & 0.016 & 0.000 \\
\hline CREDIT LYONNAIS & 0.000 & 0.000 & 0.000 \\
\hline DBS BANK & 0.119 & 0.086 & 0.056 \\
\hline DEUTSCHE BANK & -0.006 & -0.008 & 0.000 \\
\hline DRESDNER BANK & -0.136 & 0.111 & 0.027 \\
\hline GRINDLAYS BANK & -0.047 & 0.013 & -0.049 \\
\hline
\end{tabular}




\begin{tabular}{|c|c|c|c|}
\hline HONGKONG AND SHANGHAI BANK & -0.003 & 0.017 & -0.009 \\
\hline ING BANK & 0.195 & 0.002 & 0.243 \\
\hline Name & TFPG & TE Change & SE Change \\
\hline JP MORGAN CHASE BANK & 0.000 & 0.000 & 0.000 \\
\hline KBC BANK & -0.989 & -0.989 & -0.502 \\
\hline KRUNG THAI BANK & -0.015 & 0.00 & -0.015 \\
\hline MASHREQBANK & 0.000 & 0.000 & 0.000 \\
\hline MIZUHO CORPORATE BANK & -0.006 & 0.004 & 0.002 \\
\hline OMAN INTERNATIONAL BANK & -0.112 & -0.113 & 0.000 \\
\hline OVERSEAS CHINESE BANK & 1.299 & -0.000 & 1.299 \\
\hline SAKURA BANK & -0.009 & -0.004 & -0.007 \\
\hline SHINHAN BANK & -0.004 & -0.008 & 0.019 \\
\hline SIAM COMMERCIAL BANK & 0.000 & 0.000 & 0.000 \\
\hline SOCIETE GENERALE & 0.052 & 0.045 & 0.012 \\
\hline SONALI BANK & 0.000 & 0.000 & 0.000 \\
\hline STANDARD CHARTERED BANK & 0.016 & 0.006 & 0.012 \\
\hline STANDARD CHARTERED GRINDLAYS BANK & -0.352 & 0.151 & -0.260 \\
\hline STATE BANK OF MAURITIUS & 0.127 & 0.042 & 0.090 \\
\hline SUMITOMO BANK & 0.138 & -0.156 & -0.151 \\
\hline UFJ BANK & 0.027 & 0.020 & 0.013 \\
\hline
\end{tabular}


Table 18 Direct Comparison of Productivity Change of 3 Major Banks

\begin{tabular}{|c|c|c|c|}
\hline Year & SBI & HSBC & ICICI \\
\hline 1996 & 1.025 & 0.988 & 1.288 \\
\hline 1997 & 0.971 & 1.033 & 1.078 \\
\hline 1998 & 0.967 & 1.052 & 1.081 \\
\hline 1999 & 0.929 & 1.026 & 1.150 \\
\hline 2000 & 0.998 & 1.136 & 1.240 \\
\hline 2001 & 1.059 & 1.279 & 1.125 \\
\hline 2002 & 1.103 & 1.261 & 1.300 \\
\hline 2003 & 1.224 & 1.495 & 1.580 \\
\hline 2004 & 1.288 & 1.584 & 1.550 \\
\hline 2005 & 1.296 & 1.571 & 1.499 \\
\hline 2006 & 1.277 & 1.569 & 1.511 \\
\hline 2007 & 1.224 & 1.393 & 1.529 \\
\hline 2008 & 1.284 & 1.496 & 1.612 \\
\hline 2009 & 1.379 & 1.692 & 1.652 \\
\hline
\end{tabular}

Base: SBI 1992=1.0 


\section{Appendix}

\section{The Nonparametric DEA Methodology}

Consider an industry producing $m$ outputs, $y=\left(y_{1}, y_{2}, \ldots, y_{m}\right)$ using $n$ inputs, $x=\left(x_{1}, x_{2}, \ldots, x_{n}\right)$. An input-output pair $\left(x^{0}, y^{0}\right)$ is considered feasible if the output bundle $y^{0}$ can be produced from the input bundle $x^{0}$. The set of all feasible input-output bundles constitute the technology or the production possibility set

$$
T=\{(x, y): y \text { can be produced from } x\}
$$

In the single output case, one can define the production function as

$$
f(x)=\max y:(x, y) \in T .
$$

Thus, an alternative definition of the technology set is

$$
T=\{(x, y): y \leq f(x)\}
$$

In the multiple output case, a production function has to be replaced by the production correspondence

$F(x, y)$. An input-output pair $(x, y)$ is feasible only if $F(x, y) \leq 1$. In other words, the technology set is

$$
T=\{(x, y): F(x, y) \leq 1\} .
$$

The output-oriented technical efficiency of a firm using input $x^{0}$ and producing output $y^{0}$ is

$\tau_{y}\left(x^{0}, y^{0}\right)=\frac{1}{\varphi^{*}}$ where $\varphi^{*}=\max \varphi:\left(x^{0}, \varphi y^{0}\right) \in T$. In a parallel way, the input-oriented technical

efficiency of the firm is $\tau_{x}\left(x^{0}, y^{0}\right)=\theta^{*}$ where $\theta^{*}=\min \theta:\left(\theta x^{0}, y^{0}\right) \in T$. Note that both of these technical efficiency measures are radial in nature because the output vector is expanded or the input vector is contracted radially.

A generalized measure of technical efficiency defined as the Geometric Distance Function by Thanassoulis and Portela (2004) that alters inputs as well as outputs non-radially is 


$$
\gamma\left(x^{0}, y^{0}\right)=\min \frac{\left(\prod_{i=1}^{n} \theta_{i}\right)^{\frac{1}{n}}}{\left(\prod_{r=1}^{m} \varphi_{r}\right)^{\frac{1}{m}}}:\left(\theta_{1} x_{1}, \theta_{2} x_{2}, \ldots, \theta_{n} x_{n}, \varphi_{1} y_{1}, \varphi_{2} y_{2}, \ldots, \varphi_{m} y_{m}\right) \in T
$$

In this efficiency measure above each $\theta_{\mathrm{i}}$ on the input side and each $\varphi_{\mathrm{r}}$ on the output side is weighted equally. In many cases, the individual inputs and outputs are assigned different weights. In that case the Geometric Distance Function can be redefined as

$$
\gamma\left(x^{0}, y^{0}\right)=\min \frac{\left(\prod_{i=1}^{n} \theta_{i}^{\beta_{i}}\right)}{\left(\prod_{r=1}^{m} \varphi_{r}^{\alpha_{i}}\right)}:\left(\theta_{1} x_{1}, \theta_{2} x_{2}, \ldots, \theta_{n} x_{n}, \varphi_{1} y_{1}, \varphi_{2} y_{2}, \ldots, \varphi_{m} y_{m}\right) \in T
$$

In order to measure the technical efficiency of a firm in an empirical evaluation one needs to get a numerical estimate of the production possibility set, $T$. Because there are no engineering formulas that define the production possibility set, one has to construct it empirically from observed inputoutput data. There are two alternative approaches that are commonly used in practice. In the econometric approach of Stochastic Frontier Analysis (SFA) one specifies an explicit parametric form of the production function and estimates the coefficients of the function along with the parameters of the composite effort distribution by maximum likelihood procedure. The principal appeal of SFA lies in the fact that it accommodates random noise separately from inefficiency. The drawback is that its validity depends critically on the function being correctly specified. Moreover, when multiple outputs are involved one can no longer directly estimate a function relating inputs to outputs and must rely on the dual cost or profit function. The nonparametric alternative known as Data Envelopment Analysis (DEA) eschews any explicit specification of a functional form and, instead relies on a minimal set of fairly weak assumptions about the technology in order to construct a piecewise linear production frontier. A major strength of the DEA approach is its ability to accommodate multiple outputs. On the down side, it does not directly permit random noise so that any deviation from the frontier is automatically treated as inefficiency. Never the less, DEA has gained immense popularity as a benchmarking technique and especially in banking applications has been the preferred analytical method.

The starting point of DEA is an observed set of input output data from a sample of $N$ firms from an industry. Let $\left(x^{j}, y^{j}\right)$ be the input-output bundle of firm $j(j=1,2, \ldots, N)$. The following assumptions are made about the underlying technology: 
(i) All observed input-output bundles are feasible $>$ Thus, $\left(x^{j}, y^{j}\right) \in T,(j=1,2, \ldots, N)$.

(ii) Inputs are freely disposable. That is, if $x^{1} \geq x^{0}$, then $\left(x^{0}, y^{0}\right) \in T \Rightarrow\left(x^{1}, y^{0}\right) \in T$.

(iii) Outputs are freely disposable. That is, if $y^{1} \leq y^{0}$, then $\left(x^{0}, y^{0}\right) \in T \Rightarrow\left(x^{0}, y^{1}\right) \in T$.

(iv) The production possibility set is convex.

Relying on these assumptions one can construct an estimate of the technology set as

$$
S=\left\{(x, y): x \geq \sum_{j=1}^{N} \lambda_{j} x^{j} ; y \leq \sum_{j=1}^{N} \lambda_{j} y^{j} ; \sum_{j=1}^{N} \lambda_{j}=1 ; \lambda_{j} \geq 0 ;(j=1,2, \ldots, N)\right\} .
$$

Following Charnes, Cooper, and Rhodes (1978) and banker, Charnes, and Cooper (1984) we can get the radial output-oriented technical efficiency $\tau_{y}\left(x^{0}, y^{0}\right)$ of a firm with input-output $\left(x^{0}, y^{0}\right)$ by solving the linear programming problem

$$
\begin{gathered}
\varphi^{*}=\max \varphi \\
\text { s.t. } \sum_{j=1}^{N} \lambda_{j} y_{r j} \geq \varphi y_{r 0}(r=1,2, \ldots, m) \\
\sum_{j=1}^{N} \lambda_{j} x_{i j} \leq x_{i 0}(i=1,2, \ldots, n) \\
\sum_{j=1}^{N} \lambda_{j}=1 ; \lambda_{j} \geq 0(j=1,2, \ldots, N)
\end{gathered}
$$

As noted before, $\tau_{y}\left(x^{0}, y^{0}\right)=\frac{1}{\varphi^{*}}$.

Similarly, the input oriented radial measure of technical efficiency is

$$
\begin{gathered}
\tau_{x}\left(x^{0}, y^{0}\right)=\theta^{*}=\min \theta \\
\text { s.t. } \sum_{j=1}^{N} \lambda_{j} y_{r j} \geq y_{r 0}(r=1,2, \ldots, m) \\
\sum_{j=1}^{N} \lambda_{j} x_{i j} \leq \theta x_{i 0}(i=1,2, \ldots, n) \\
\sum_{j=1}^{N} \lambda_{j}=1 ; \lambda_{j} \geq 0(j=1,2, \ldots, N)
\end{gathered}
$$


A problem with a radial measure of technical efficiency, whether input- or output-oriented, is that it ignores slacks in the input or output constraints that may (and usually do) exist at the optimal solution of the relevant DEA LP problem. This implies potential for further reduction in individual inputs and/or increase in individual outputs. In that sense, the efficient project is not necessarily Pareto efficient. The generalized efficiency measure obtained from the Geometric Distance Function takes account of all possible reduction in inputs and all possible increase in outputs. It, therefore, is a more complete measure of the efficiency of the firm. To obtain the (weighted) generalized measure of efficiency we solve the following mathematical programming problem:

$$
\begin{gathered}
\gamma\left(x^{0}, y^{0}\right)=\min \frac{\left(\prod_{i=1}^{n} \theta_{i}^{\beta_{i}}\right)}{\left(\prod_{r=1}^{m} \varphi_{r}^{\alpha_{i}}\right)} \\
\text { s.t. } \sum_{j=1}^{N} \lambda_{j} y_{r j} \geq \varphi_{r} y_{r 0}(r=1,2, \ldots, m) \\
\sum_{j=1}^{N} \lambda_{j} x_{i j} \leq \theta_{i} x_{i 0}(i=1,2, \ldots, n) \\
\sum_{j=1}^{N} \lambda_{j}=1 ; \lambda_{j} \geq 0(j=1,2, \ldots, N)
\end{gathered}
$$

It may be noted that this is a non-linear programming problem. However, instead of maximizing the objective function directly, one may want to maximize the log of the objective function

$$
\ln \gamma=\sum_{i=1}^{n} \beta_{i} \ln \theta_{i}-\sum_{r=1}^{m} \alpha_{r} \ln \varphi_{r}
$$

A linear approximation of $\ln \gamma$ is

$$
\ln \gamma \approx \ln \gamma^{0}+\sum_{i=1}^{n} \frac{\beta_{i}}{\theta_{i}^{0}} \theta_{i}-\sum_{r=1}^{m} \frac{\alpha_{r}}{\varphi_{r}^{0}} \varphi_{r} \text { where }\left(\theta^{0}, \varphi^{0}\right) \text { is the point of approximation. }
$$

Using $\theta_{i}^{0}=1$ and $\varphi_{r}^{0}=1$ for each input $i$ and output $r$, we get

$$
\ln \gamma \approx \sum_{i=1}^{n} \beta_{i} \theta_{i}-\sum_{r=1}^{m} \alpha_{r} \varphi_{r}
$$


The optimal solution from this linearized model can be used to evaluate the generalized technical efficiency.

Another point to be noted here is that in the nonlinear programming problem above, we permit inputs to increase or outputs to decrease, if in the end the objective function is minimized. The conventional measure of technical efficiency only permits decline in inputs and increase in the levels of outputs. This can be accommodated by imposing the relevant additional constraints in the DEA problem (A10) above. If the constraints are binding, the optimal solution will be different from what was obtained without these constraints. As shown by Ray and Chen (2011), the optimal projection obtained from the solution of (A10) is a point of maximum total factor productivity on the frontier and, by virtue of being a most productive scale size, exhibits locally constant returns to scale. The total factor productivity at the restricted projection relative to this most productive scale size reflects scale efficiency of the observed bundle. This is explained using a diagram in Figure 1. Points A and B represent the actual input-output bundles of two firms. The broken line segment KLDCFMN is the frontier of the production possibility set constructed from the data. Average productivity at A is $A P_{A}=\frac{O y_{A}}{O x_{A}}$ while the maximum average productivity $A P^{*}=\frac{O y^{*}}{O x^{*}}$ is attained at C. Define, $\left(\theta_{A}=\frac{O x^{*}}{O x_{A}}, \varphi_{A}=\frac{O y^{*}}{O y_{A}}\right)$. Thus, the generalized efficiency of A is $\gamma_{A}=\frac{A P_{A}}{A P^{*}}=\frac{\theta_{A}}{\varphi_{A}}$. Similarly, the generalized efficiency of B is $\gamma_{B}=\frac{A P_{B}}{A P^{*}}=\frac{\theta_{B}}{\varphi_{B}}$. This shows that $\pi_{A \mid B}=\frac{A P_{A}}{A P_{B}}=\frac{\gamma_{A}}{\gamma_{B}}$. Now suppose increasing input or decreasing output is not allowed. In that case, an efficient projection of A must be restricted to the segment of the frontier that lies towards the northwest of the point $\mathrm{A}$. This is the point $\mathrm{D}$ (on the frontier) obtained by solving the constrained version of the problem (A10). This time, the generalized efficiency $\gamma_{A}=\frac{A P_{A}}{A P^{*}}$ can be factorized as

$$
\frac{A P_{A}}{A P^{*}}=\frac{A P_{A}}{A P_{D}} \cdot \frac{A P_{D}}{A P_{*}^{*}} .
$$

In this decomposition $\frac{A P_{A}}{A P_{D}}$ is pure technical efficiency while $\frac{A P_{D}}{A P^{*}}$ is the scale efficiency. Similarly, the pure technical efficiency of B is $\frac{A P_{B}}{A P_{F}}$ while scale efficiency is $\frac{A P_{F}}{A P^{*}}$.

As is well known in the DEA literature, if one assumed globally constant returns, the constraint $\sum_{j=1}^{N} \lambda_{j}=1 ; \lambda_{j} \geq 0(j=1,2, \ldots, N)$ would be eliminated and the frontier would be ray OECG. In 
that case, the efficient projection of A without increasing inputs and reducing outputs would be the point D. Similarly, the restricted projection of B under CRS would be the point G. But under CRS total factor productivity remains same across all points on the frontier. Hence, $A P_{E}=A P^{*}=A P_{G}$. Hence, the pure technical efficiency will be the same as the generalized efficiency.

\section{Technical Change}

When technological change is allowed, the production possibility set changes and the corresponding frontier shifts over time. In DEA, the production possibility set is the so called free disposal convex hull of the input output vectors that are considered to be feasible at during that time period. By assumption, an input-output bundle that is actually observed at time $t$ is feasible. Hence, all convex combinations of these bundles will necessarily lie within the technology set. If we consider past observations to be feasible in subsequent periods even though they were not actually observed in a later period, the technology set is the free disposal convex hull of all current and past observations. This leads to what is known as a sequential frontier and technological change is treated as non-regressive. Often, due to regulatory changes, an inputoutput bundle that was feasible in the past no longer remains feasible in later years. For example, stricter pollution control standards require diversion of capital equipment from power generation to pollution abatement. As a result, the maximum amount of power producible from the same input bundle may be lower than before. In such cases, the technology for any period is constructed from input-output data from that period alone. This would allow the frontier to shift inwards as well as outwards.

To measure technical change we need to solve the cross period technical efficiency of the input-

output bundle $\left(x^{0}, y^{0}\right)$ from period 0 against the frontier from period 1 . This can be obtained by solving the optimization problem 


$$
\begin{gathered}
\gamma^{i}\left(x^{0}, y^{0}\right)=\min \frac{\left(\prod_{i=1}^{n} \theta_{i}^{\beta_{i}}\right)}{\left(\prod_{r=1}^{m} \varphi_{r}{ }^{\alpha_{i}}\right)} \\
\text { s.t. } \sum_{j=1}^{N} \lambda_{j} y_{r j}^{1} \geq \varphi_{r} y^{0}{ }_{r 0}(r=1,2, \ldots, m) \\
\sum_{j=1}^{N} \lambda_{j} x_{i j}^{1} \leq \theta_{i} x^{0}{ }_{i 0}(i=1,2, \ldots, n) \\
\sum_{j=1}^{N} \lambda_{j}=1 ; \lambda_{j} \geq 0(j=1,2, \ldots, N)
\end{gathered}
$$

It may be noted that in this optimization problem the period 0 input-outputs of the firm appear on the right hand sides on the constraints while some convex combination of the input-output bundles of the firms from period 1 appear on the left hand sides. The optimal value of the problem (A13), $\gamma^{1}\left(x^{0}, y^{0}\right)$, measures the cross period efficiency of the input-output bundle $\left(x^{0}, y^{0}\right)$ against the frontier from period 1 . The other cross period efficiency $\gamma^{0}\left(x^{1}, y^{1}\right)$ can also be measured in an analogous manner.

The diagram in Figure 2 explains the concept of technical change defined above. In Figure 2, the piece-wise connected line $\mathrm{K}_{0} \mathrm{~L}_{0} \mathrm{Q}_{0} \mathrm{M}_{0} \mathrm{~N}_{0} \mathrm{~S}_{0}$ is the frontier from period 0 while $\mathrm{K}_{1} \mathrm{~L}_{1} \mathrm{Q}_{1} \mathrm{M}_{1} \mathrm{~N}_{1} \mathrm{~S}_{1}$ is the frontier from period 1 . The point $\mathrm{P}_{0}$ shows the input-output of the firm in period 0 . The generalized efficiency of $\left(x^{0}, y^{0}\right)$ is $\gamma^{0}\left(x^{0}, y^{0}\right)=\frac{A P\left(P_{0}\right)}{A P\left(Q_{0}\right)}$ in period 0 and $\gamma^{1}\left(x^{0}, y^{0}\right)=\frac{A P\left(P_{0}\right)}{A P\left(Q_{1}\right)}$ in period 1. The measured technical change is $\frac{\gamma^{0}\left(x^{0}, y^{0}\right)}{\gamma^{1}\left(x^{0}, y^{0}\right)}$. A value of this ratio less than 1 implies that there has been a technical progress between period 0 and period 1 . 


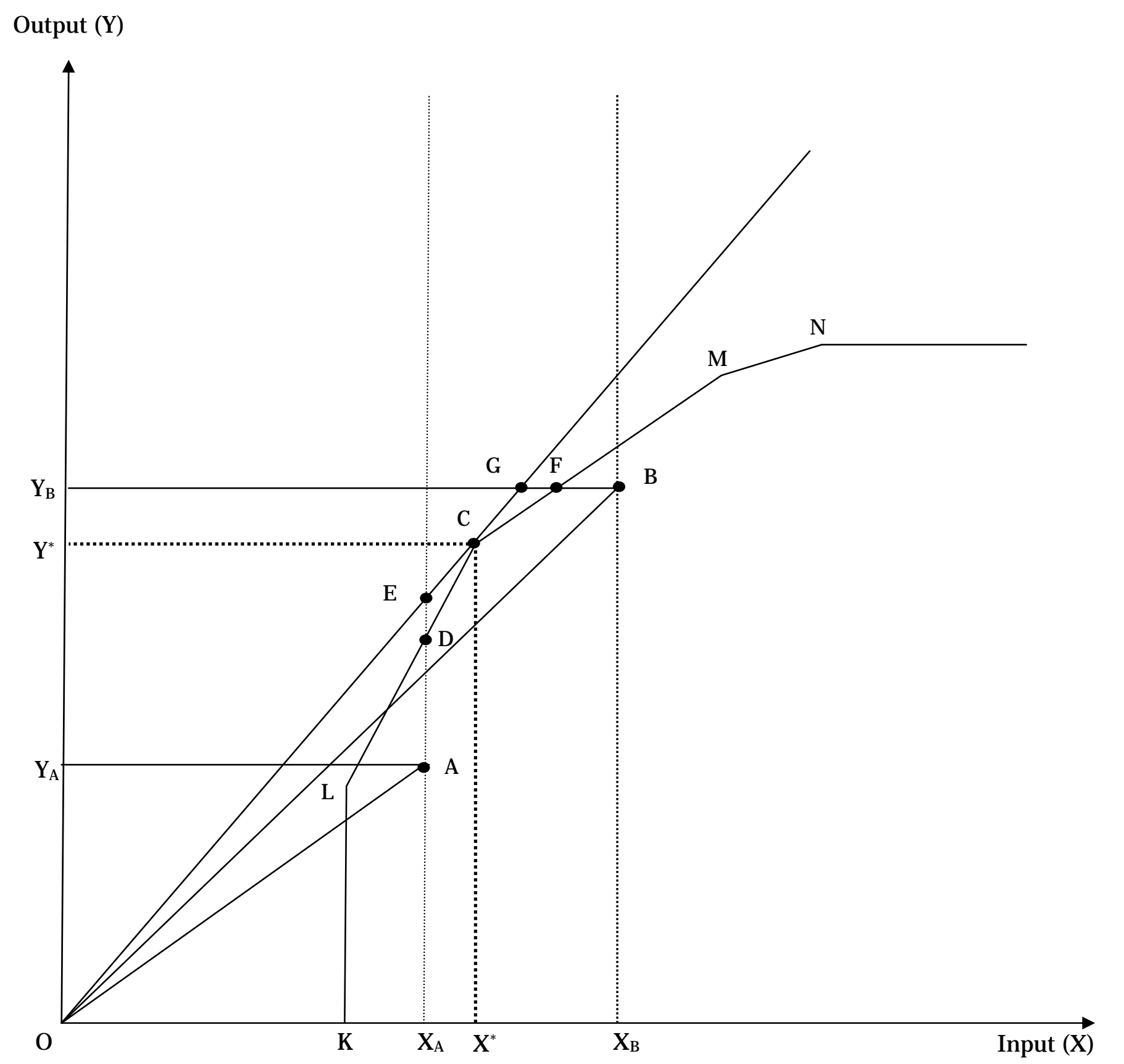

Figure 1: Measure of Technical Efficiency 


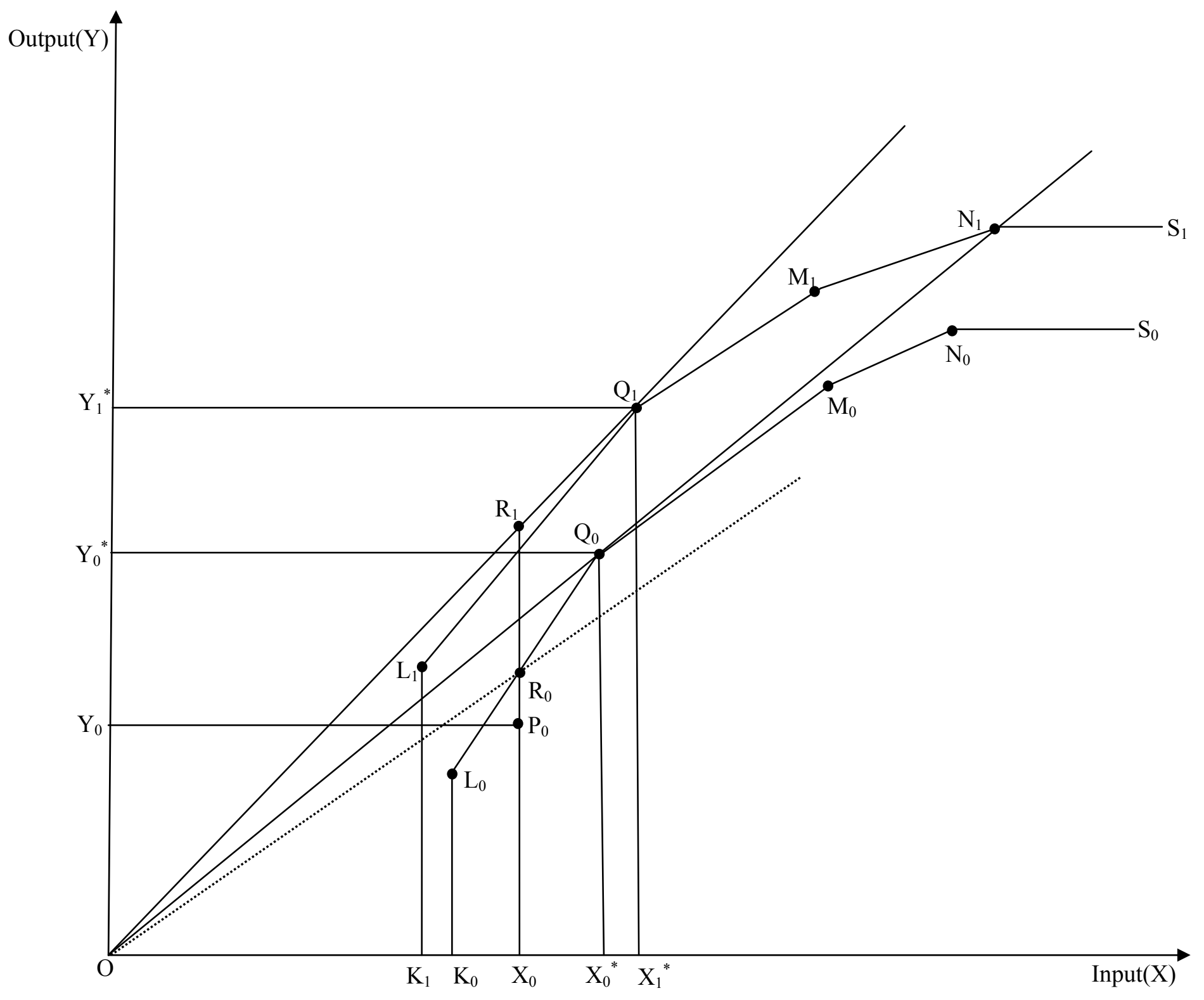

Figure 2: TFPG and Technical Change 


\section{References:}

Banerjee, A.V., S. Cole, and E.Duflo (2004) "Banking Reform in India"; MIT Working Paper.

Bhattacharyya, A., C.A.K. Lovell, and P. Sahay (1997) "The Impact of Liberalization on the

Productive Efficiency of Indian Commercial Banks"; European Journal of Operational Research, Vol 98, pp 332-345.

Chakrabarti, R, (2009) "Banking in India: Reforms and Reorganization";

Das, A., Ghosh, S., 2006. Financial deregulation and efficiency: an empirical analysis of Indian banks during the post-reform period. Review of Financial Economics $15,193-221$.

Das, A., A. Nag, and S.C. Ray (2005) "Liberalization, Ownership, and Efficiency in Indian Banking: A Nonparametric Approach"; Economic and Political Weekly, March 19, 2005, pp 1190-1197.

Das, S.K. "Financial Liberalization and Banking Sector Efficiency: The Indian Experience"; Paper presented at the12th Money and Finance Conference, 11 - 12th March 2010 IGIDR, Mumbai

Ketkar, K.W. and S. L. Ketkar (2008) "Performance and Profitability of Indian Banks in the Post Liberalization Period"; Paper presented at the 2008 World Congress on National Accounts and Economic Performance Measures for Nations, May 13-17, 2008, Washington DC.

Kumbhakar, S.C., Sarkar, S.,(2003) “ Deregulation, ownership and productivity growth in the banking industry: evidence from India". Journal of Money, Credit, and Banking 35, 403414.

Mohan, R. (2004) "Ownership and Governance in Private Sector Banks in India"; Reserve Bank of India Bulletin, Oct 2004, pp 879-883

Mohan, R. (2005) "Reforms, Productivity, and Efficiency in Banking: The Indian Experience"; The Pakistan Development Review 44 : 4 Part I (Winter 2005) pp. 505-538.

Narashimham Committee (1992) Report of the Committee on the Financial System", "; Reserve Bank of India Bulletin, Feb 1992, pp 369-380. 
Portela MCS, Thanassoulis E (2005) "Profitability of a sample of Portuguese bank branches and its decomposition into technical and allocative components". Eur J Oper Res 162(3): 850-866

Portela, M. and E. Thanassoulis "Malmquist indexes using a geometric distance function (GDF). Application to a sample of Portuguese bank branches"; Journal of Productivity Analysis 2007

Ram Mohan, T.T. and S.C. Ray (2003) "Productivity and Efficiency at Public and Private Banks in India"; paper presented at the Fifth Annual Conference on Money and Finance in the Indian Economy, Indira Gandhi Institute of Development Research, Mumbai.

Ram Mohan, T.T. and S.C. Ray (2004) "Comparing Performance of Public and Private Sector Banks: A Revenue maximization Efficiency Approach"; Economic and Political Weekly, Vol 39, No 12, pp 1271-1276

Rangarajan, C. (2007) “The Indian Banking System - Challenges Ahead” Speech delivered at the Indian Institute of Bankers.

Portela, M. and E. Thanassoulis "Malmquist indexes using a geometric distance function (GDF). Application to a sample of Portuguese bank branches"; Journal of Productivity Analysis 2007

Ray, S.C. and L. Chen (2011) A Normative Interpretation of the Tornqvist Productivity Index “; Paper presented at the $9^{\text {th }}$ International Conference on DEA at Thessaloniki, Greece in August 2011.

Ray, S.C. and A. Das (2009) "Distribution of cost and profit efficiency: Evidence from Indian Banking"; European Journal of Operational Research xxx (2009) xxx-xxx

Reddy, Y. V. (2002) “ Public Sector Banks and the Governance Challenge: Indian Experience. Lecture delivered at the World Bank, IMF and Brookings Institutions Conference, April 2002.

Reserve Bank of India (2010) Report on Trend and Progress of Banking in India 2010, Mumbai, RBI.

Reserve Bank of India (2010) Statistical Tables Relating to Banks in India 2009-10, Mumbai, RBI.

Sanyal, P. and R. Shankar (2008) "Ownership, Competition and Bank Productivity: An Analysis of Indian Banking in the Post-Reform Period"; 
Sarkar, S., J. Sarkar, and S. Bhaumik (2008) "Does Ownership Always Matter? Evidence from the Indian banking Industry"; Journal of Comparative Economics Vol 26, pp 262-281.

Sensarma, R.(2006) “ Are foreign banks always the best? Comparison of state-owned, private and foreign banks in India"; Economic Modeling 23, pp 717-735

Shammugam, K.R. and A. Das (2004) "Efficiency of Indian Commercial Banks during the Reform Period”; Applied Financial Economics, Vol 14, pp 681-686.

Wanniarachchige, M. and Y. Suzuki (2011) "Performance Dynamics Of Indian Commercial Banks: Does Ownership Matter?"; Paper presented at the 2011 Maui International Conference.

Zhao, T., B. Casu, and A. Ferrari (2010) "The impact of regulatory reforms on cost structure, ownership and competition in Indian banking"; Journal of Banking \& Finance 34, pp 246-254 